\title{
Immunology and Technology of Severe Acute Respiratory Syndrome Coronavirus 2 (SARS-CoV-2) Vaccines
}

\author{
Simone Pecetta, Sven Kratochvil, Yu Kato, Kumaran Vadivelu, and Rino Rappuoli \\ Research and Development Centre, GSK, Siena, Italy (S.P., K.V., R.R.); Ragon Institute of Massachusetts General Hospital, Massachusetts \\ Institute of Technology, and Harvard University, Cambridge, Massachusetts (S.K.); IconOVir Bio, San Diego, California (Y.K.); and La Jolla \\ Institute for Immunology, La Jolla, California (Y.K.)
}

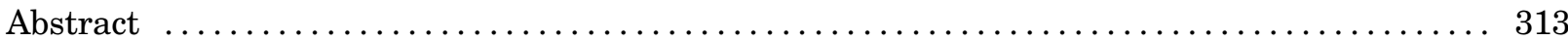

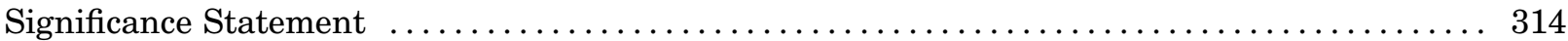

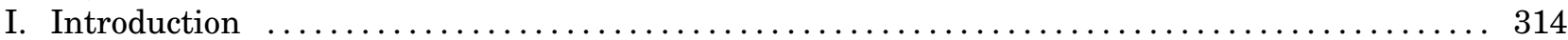

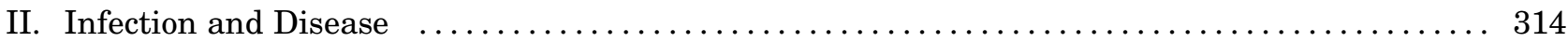

A. Emergence of Severe Acute Respiratory Syndrome Coronavirus 2 (SARS-CoV-2) $\ldots \ldots \ldots 314$

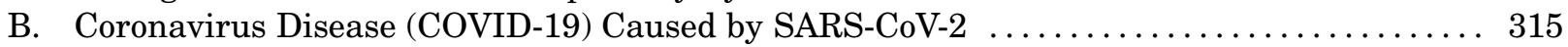

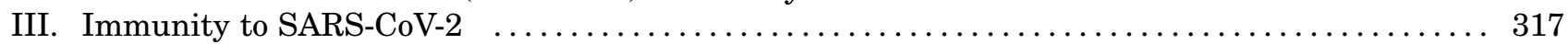

A. Targets of Antibody-Mediated Immunity $\ldots \ldots \ldots \ldots \ldots \ldots \ldots \ldots \ldots \ldots \ldots \ldots \ldots \ldots \ldots \ldots$

B. T Cell Responses .................................................... 319

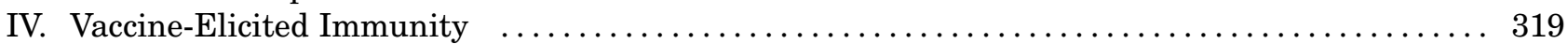

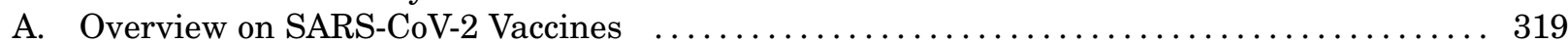

B. Immunogenicity and Efficacy of the Different Vaccine Platforms

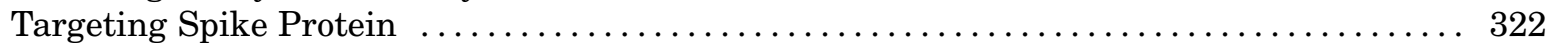

1. Inactivated and Attenuated SARS-CoV-2 Vaccines $\ldots \ldots \ldots \ldots \ldots \ldots \ldots \ldots \ldots \ldots \ldots \ldots \ldots \ldots \ldots \ldots$

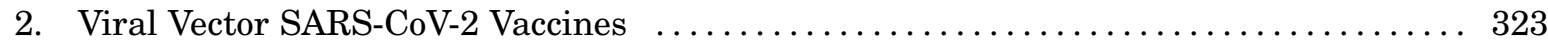

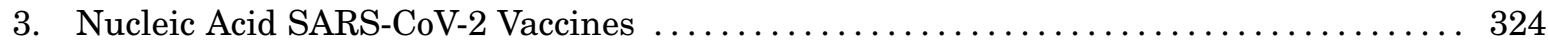

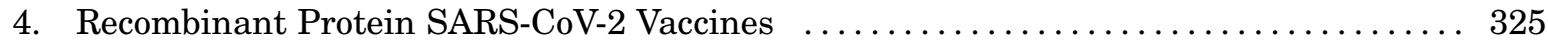

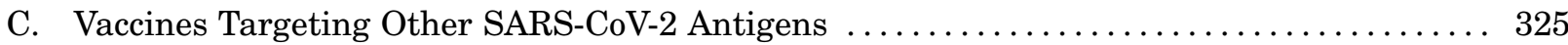

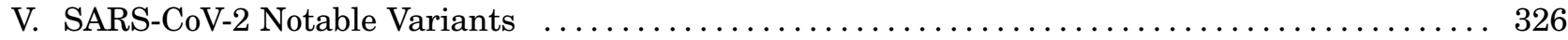

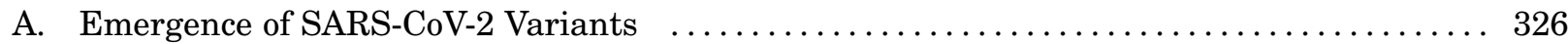

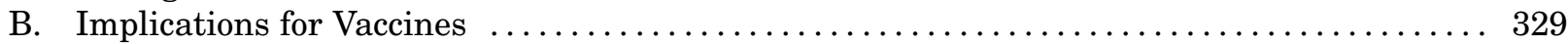

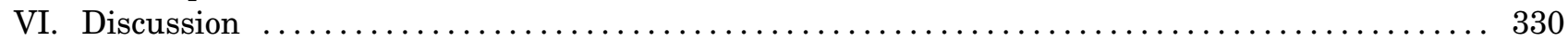

A. Considerations on Immune Response to Natural Infection and Vaccination $\ldots \ldots \ldots \ldots 330$

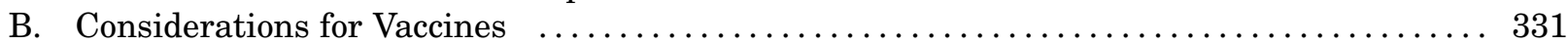

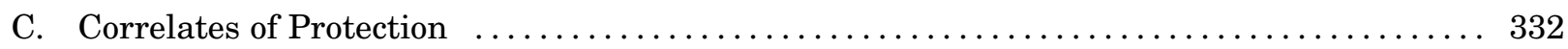

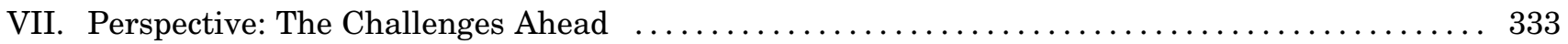

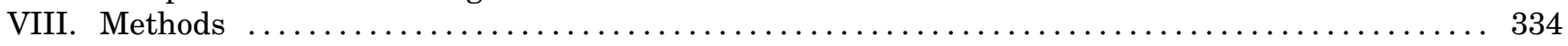

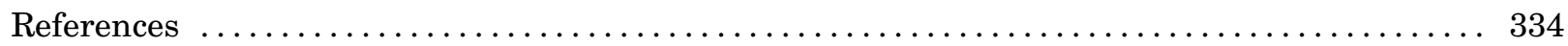

\begin{abstract}
We have experienced an enormous cohesive effort of the scientific community to understand how the immune system reacts to severe acute respiratory syndrome coronavirus 2 (SARS-CoV-2) and how to elicit protective immunity via vaccination. This effort resulted in the development of vaccines in record time with high levels of safety, efficacy, and real-life

effectiveness. However, the rapid diffusion of viral variants that escape protective antibodies prompted new studies to understand SARS-CoV-2 vulnerabilities and strategies to guide follow-up actions to increase, and maintain, the protection offered by vaccines. In this review, we report the main findings on human immunity to SARS-CoV-2 after natural infection
\end{abstract}

Address correspondence to: Dr. Rino Rappuoli, GSK, via Fiorentina 1, 53100 Siena, Italy. E-mail: rino.r.rappuoli@gsk.com

This work was supported by GlaxoSmithKline Biologicals SA, which was involved in all stages and covered the costs associated with the development and publishing of this manuscript.

S.P., K.V., and R.R. are full-time employees of the GSK group of companies. K.V. and R.R. hold shares in the GSK group of companies as part of their remuneration. S.K. and Y.K. do not have an actual or perceived conflict of interest with the contents of this article.

dx.doi.org/10.1124/pharmrev.120.000285. 
and vaccination; we dissect the immunogenicity and efficacy of the different vaccination strategies that resulted in products widely used in the population; and we describe the impact of viral variants on vaccine-elicited immunity, summarizing the main discoveries and challenges to stay ahead of SARS-CoV-2 evolution.

Significance Statement_— This study reviewed findings on human immunity to severe acute respiratory syndrome coronavirus 2 (SARS-CoV-2), analyzed the immunogenicity and efficacy of the various vaccines currently used in large vaccination campaigns or candidates in advanced clinical development, and discussed the challenging task to ensure high protective efficacy against the rapidly evolving SARS-CoV-2 virus. This manuscript was completed prior to the emergence of the Omicron variant and to global vaccine boosting efforts.

\section{Introduction}

Nearly two years have passed since the discovery of a novel severe acute respiratory syndrome coronavirus 2 (SARS-CoV-2) causing coronavirus disease (COVID-19) in Wuhan, China. The sudden emergence and rapid spread around the globe of SARS-CoV-2 drove many of the world's governments to implement far-reaching health measures such as mandatory mask wearing, restrictions on public gathering and travel, and requirements for physical distancing to stop uncontrolled viral transmission, all in an effort to safeguard the public's health. Significant funds were committed by both public authorities and private enterprises to find interventions against COVID19. Large-scale efforts were conducted by the scientific community to understand the biology, pathology, and epidemiology of SARS-CoV-2 and to identify potential determinants of immunity in the human host. This rapidly growing trove of scientific knowledge was made publicly available at unprecedented levels and provided the foundation for the development of new treatments and vaccines with the clear objective of stopping the pandemic. In this review, we gather evidence of natural and vaccine-induced immunity against SARS-CoV-2, the role of vaccine platforms in eliciting protective immunity, the impact of emerging virus variants with increased infectiveness and resistance to antibody-mediated neutralization, and current and future challenges that threaten the progress the world has made in stopping the pandemic.

\section{Infection and Disease}

Viruses have evolved to colonize and replicate within their hosts, deploying multiple strategies that ensure their survival. Similarly, our immune system has developed a multiplicity of mechanisms to counteract viral infection (Abbas et al., 2012). In Fig. 1, we summarize the main features of antibody- and T cellmediated immunity, which are important for understanding the immune response to SARS-CoV-2 in the following sections of this review.

\section{A. Emergence of Severe Acute Respiratory Syndrome Coronavirus 2 (SARS-CoV-2)}

The newly emerged SARS-CoV-2 belongs to the family of coronaviruses, highly infectious viruses of zoonotic origin that can be both endemic, with seasonal patterns, and epidemic, with sudden appearance in the human population after spillover from animal hosts. Particularly, severe acute respiratory syndrome coronavirus (SARS-CoV-1) and Middle East respiratory syndrome coronavirus (MERS$\mathrm{CoV}$ ) originated in market civets and dromedary camels causing fatal outbreaks of respiratory illness in 2002-2003 and 2012, respectively [reviewed in (Cui et al., 2019)]. Other seasonal coronaviruses, HCoV-NL63, HCoV-229E, HCoV-OC43, and HKU1, induce mild upper respiratory disease in immunocompetent human hosts (Su et al., 2016). Importantly, no licensed vaccines against coronaviruses were available in humans when SARS-CoV-2 suddenly emerged.

All coronaviruses are enveloped by a lipid bilayer membrane of spherical shape with a diameter of approximately $150 \mathrm{~nm}$ and decorated by the spike (S) trimeric protein, the main viral receptor that gives the virus the typical sun-like shape when observed using an electron microscope [reviewed by (Chen et al., 2020)]. The $\mathrm{S}$ protein is divided into the $\mathrm{S} 1$ and $\mathrm{S} 2$ subunits, which are responsible for binding to the human angiotensin-converting enzyme 2 (ACE2) and fusing with the cellular membrane of alveolar epithelial cells and other cell types, respectively, determining viral entry. The envelope (E) protein, involved in virion assembly and envelope formation, and the membrane (M) protein, which stabilizes the envelope and binds the nucleocapsid on its internal side, are also part

ABBREVIATIONS: ACE2, angiotensin-converting enzyme 2; ADE, antibody-dependent enhancement; COVID-19, infectious disease caused by the SARS-CoV-2 virus; E, envelope; EU, European Union; EUA, emergency use authorization; FDA, U.S. Food and Drug Administration; GMT, geometric mean titer; M, membrane; mAb, monoclonal antibody; MERS-CoV, Middle East respiratory syndrome coronavirus; N, nucleocapsid; NHP, nonhuman primate; NTD, N-terminal domain; PCR, polymerase chain reaction; RBD, receptor binding domain; RSV, respiratory syncytial virus; S, spike; SARS-CoV-1, severe acute respiratory syndrome coronavirus; SARS-CoV-2, severe acute respiratory syndrome coronavirus 2; VH3-53, IgG heavy-chain variable region 3-53; VLP, viruslike particle; VOC, variant of concern; WHO, World Health Organization. 


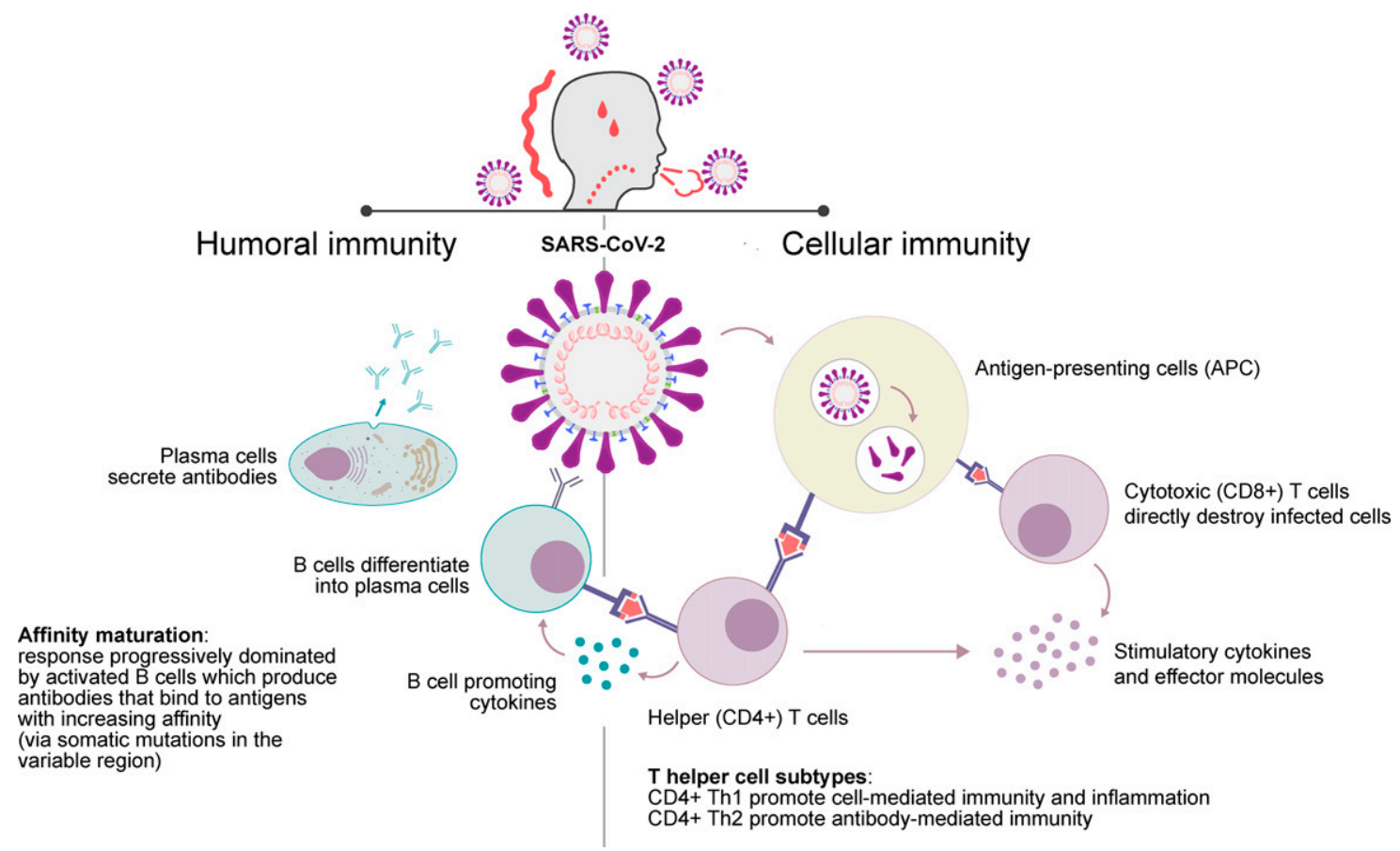

Fig. 1. Basics of antibody and cell-mediated immunity. After encounter with the virus, immune cells known as antigen-presenting cells activate antigen-specific $\mathrm{T}$ cells that act either as support to other cell types by producing cytokines and stimulatory molecules (CD4+, also referred to as helper T cells) or attack the infected cells participating in infection clearance (CD8+, also referred to as cytotoxic T cells). Helper T cells can be further divided in Th1, Th2, or other subtypes, which differentially affect the immune effector response. Antigen-specific B cells, also acting as antigen-presenting cells, are activated by helper T cells and either immediately start producing antibodies or undergo affinity maturation into the germinal center of secondary lymphoid tissues (not represented in the figure) before differentiating into plasma cells that produce high affinity antibodies that neutralize the virus (Abbas et al., 2012).

of the envelope. Within the envelope, the nucleocapsid $(\mathrm{N})$ protein is complexed with the positive, single-stranded RNA genome encoding for the aforementioned functional proteins, the replicase (ORF1a/ORF1b) and several accessory species-specific proteins relevant to viral replication (Chen et al., 2020) (Fig. 2A).

The novel virus SARS-CoV-2 is closely related to SARS-CoV-1-with around 80\% genome homologyand other coronaviruses of bat origin [reviewed by (Hu et al., 2021)] (Chan et al., 2020). SARS-CoV-2 was first reported in December 2019 in Wuhan, China, and isolated in January 2020 from patients suffering from viral pneumonia (Zhu et al., 2020c). Its viral genome was sequenced using a metagenomics approach and, within a month, the sequence was shared globally via the Global Initiative on Sharing Avian Influenza Data initiative, prompting a rapid response from the scientific community (Rappuoli et al., 2021). Along with many similarities to SARS$\mathrm{CoV}-1$, the new virus had a distinct $\mathrm{S}$ protein with a four-amino acid residues insertion in the junction between $\mathrm{S} 1$ and $\mathrm{S} 2$, which generated a polybasic cleavage site enabling furin cleavage (Coutard et al., 2020). Like other coronaviruses, SARS-CoV-2 requires proteolytic processing of the $\mathrm{S}$ protein to induce cell-cell fusion, thus the insertion of a functional furin cleavage site was associated with enhanced cell entry and virulence (Andersen et al., 2020)

\section{B. Coronavirus Disease (COVID-19) Caused by SARS- $\mathrm{CoV}-2$}

The pathogenesis of COVID-19 starts with SARS-CoV2 binding to epithelial cells in the respiratory tract, expressing ACE2. Rapid viral replication after migration to the lungs triggers an immune response. Individuals infected with SARS-CoV-2 can be asymptomatic, effectively controlling the infection, or can present mild symptoms such as chest pain, respiratory discomfort, and pneumonia, potentially progressing to severe clinical manifestations, such as respiratory compromise, systemic inflammatory syndrome, and finally multiorgan failure and death (summarized in Fig. 3) (Brodin, 2021; Hu et al., 2021; Sudre et al., 2021).

Dysregulation of inflammatory cytokines with the elevated release of interleukins IL-1, IL-6, IL-8, and tumor necrosis factor alpha, defined as "cytokine storm," is a hallmark of coronaviruses dissemination correlated with severe disease and poor prognosis 

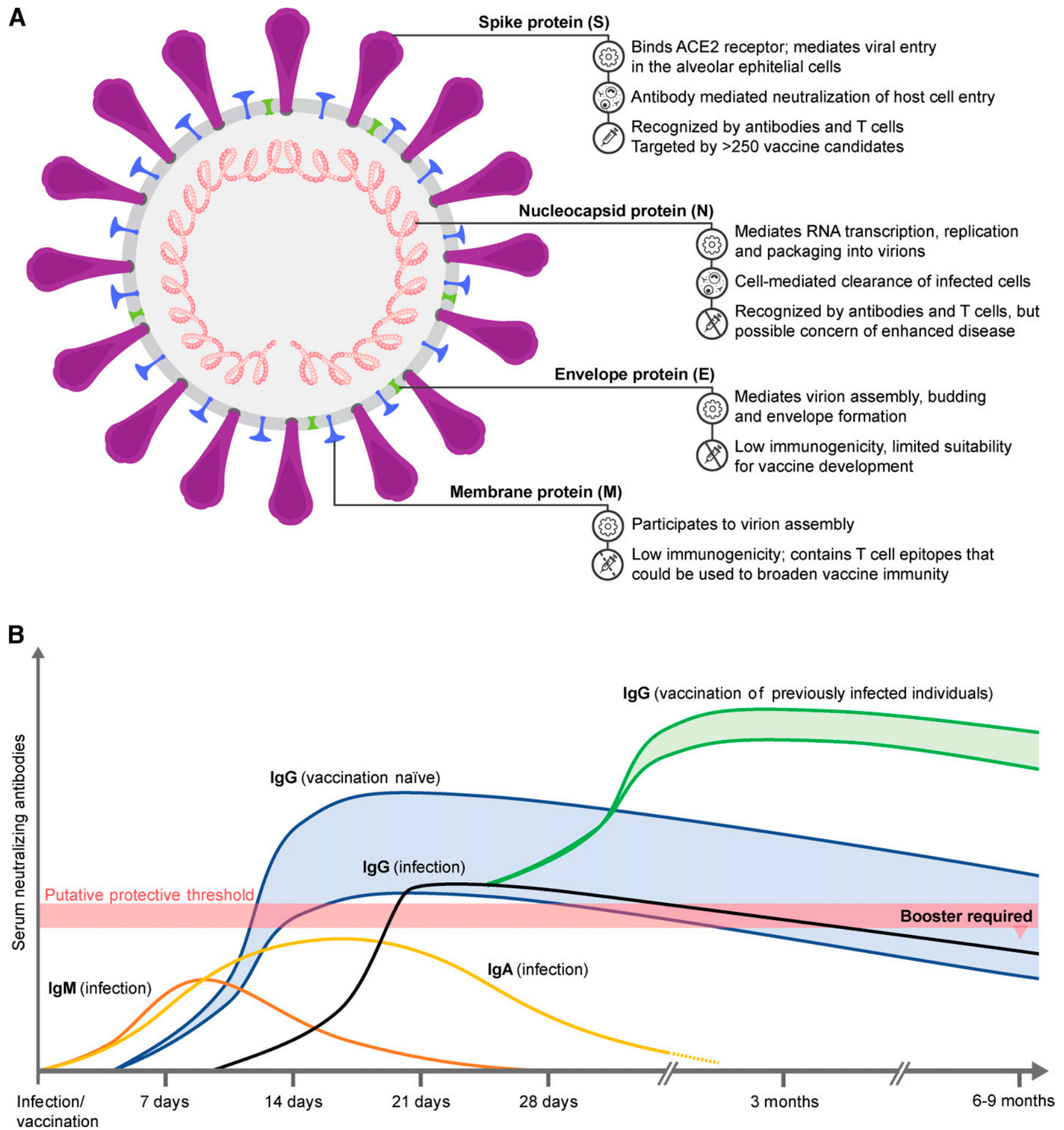

Fig. 2. Immunity to SARS-CoV-2. (A) Immunologic targets of SARS-CoV-2, highlighting the four main viral antigens. (B) Plot of putative correlation of neutralizing antibody levels with protection from infection and disease. A first wave of IgM and IgA antibodies might confer a degree of protection against SARS-CoV-2, but their levels rapidly decrease. On the contrary, IgG antibodies, appearing later during natural infection, are mostly correlated with protection. In case of active immunization, neutralizing IgG responses are induced in naïve individuals, with levels varying depending on the vaccine platform and immunization strategy used. In the case of vaccination of previously infected individuals, neutralizing IgG levels are much higher, boosting memory B cell responses developed during natural infection. In time, IgG levels might decrease below a protective threshold, requiring booster vaccination.

(Channappanavar and Perlman, 2017; Huang et al., 2020b). In particular, virus-induced proinflammatory levels of IL- 6 have been hypothesized to increase the risk of fatal disease (Santa Cruz et al., 2021). The cytokine storm has been mostly associated with patients over 60 years of age and with pre-existing medical conditions (Liu et al., 2020b; Ragab et al., 2020). 


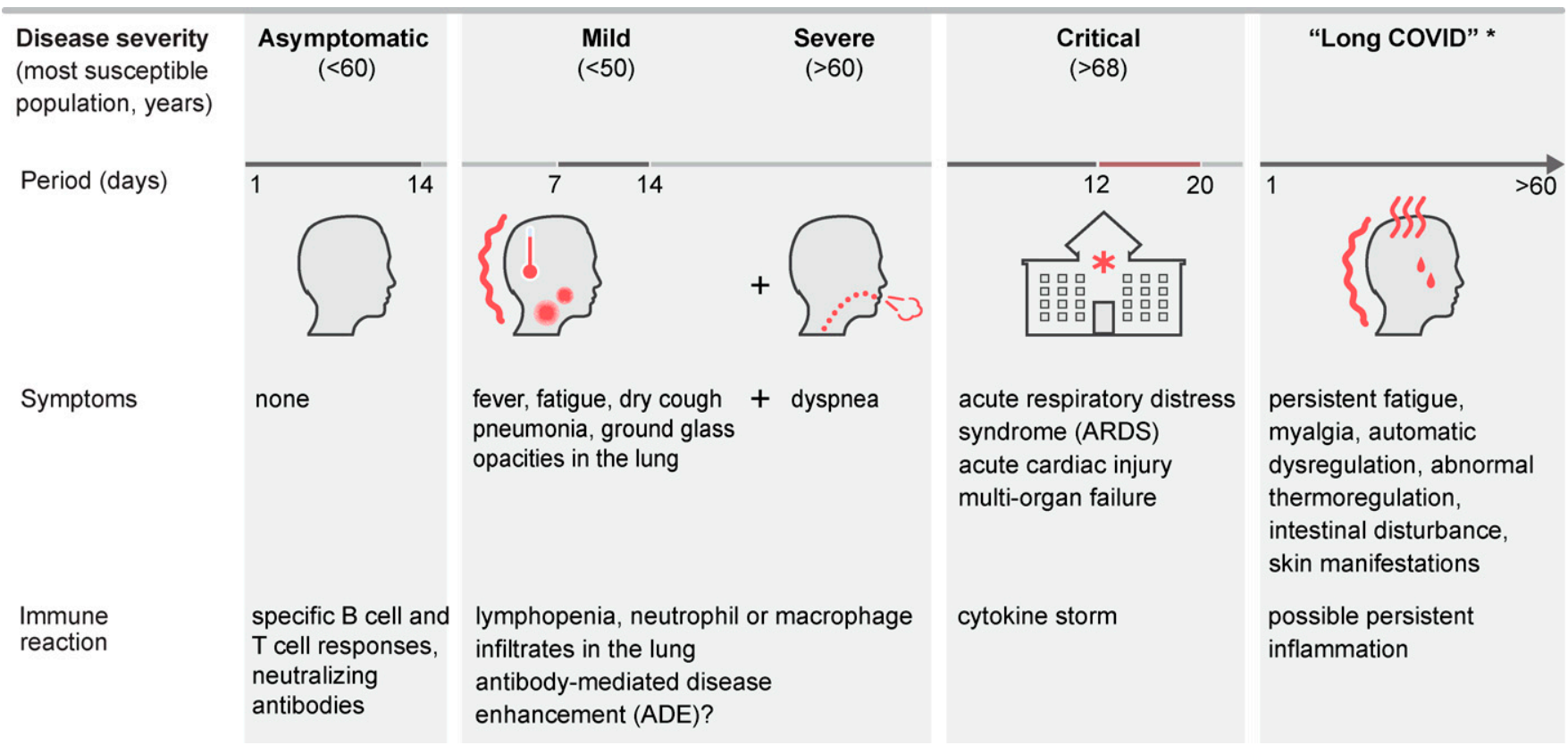

Fig. 3. Clinical features of COVID-19. SARS-CoV-2 infection is characterized by three stages of acute infection of progressive severity. After the acute phase, a period of persistent disease can occur (Brodin, 2021; Hu et al., 2021; Sudre et al., 2021). *Postacute sequalae in $<5 \%$ of patients (Sudre et al., 2021).

After remission of severe illness, some individuals, the so called COVID long-haulers, suffer from debilitating symptoms for extended periods of time, often lasting for several months. This condition, dubbed "long COVID", resembles postdisease syndromes associated with chikungunya and Ebola virus infections (Brodin, 2021; Korompoki et al., 2021).

\section{Immunity to SARS-CoV-2}

In the first months of the COVID-19 pandemic, the identification of determinants of immunity to SARSCoV-2 became paramount for guiding patient treatment strategies and vaccine design. Emerging data gathered from animal models and from patients recovering from COVID-19 revealed the importance of both humoral and cellular immunity to protect from SARS-CoV-2 and other coronaviruses infection [reviewed by (Dai and Gao, 2021; Huang et al., 2020a; Poland et al., 2020)].

\section{A. Targets of Antibody-Mediated Immunity}

Antibodies are the primary defense mechanism against viruses, blocking viral receptor binding and inhibiting viral entry and replication. Mechanistically, antibodies against the SARS-CoV-2 S protein neutralize the virus by blocking its interaction with ACE2 on the surface of alveolar epithelial cells in the lower respiratory tract and other cell types, a phenomenon observed both for SARS-CoV-1 and SARS-CoV-2 (Ju et al., 2020; Lan et al., 2020; Song et al., 2018; Wan et al., 2020; Wrapp et al., 2020). Evidence of immunodominance of the $\mathrm{S}$ protein came from both SARSCoV-1 and SARS-CoV-2 studies, which identified the receptor binding domain $(\mathrm{RBD})$ in the $\mathrm{S} 1$ subunit of the $\mathrm{S}$ protein as the main target of antibody-dependent neutralization (Wong et al., 2004; Woo et al., 2005; Premkumar et al., 2020). Indeed, antibodies targeting RBD accounted for $90 \%$ of the convalescent serum neutralizing activity (Piccoli et al., 2020). The kinetics of the antibody response in COVID-19 patients is characterized by rapid seroconversion 7-14 days after symptom onset (Norman et al., 2020). In longitudinal studies, IgM and IgA antibodies are the first antibodies to be detected, which peak at 10-12 days (IgM) and 20-22 days (IgA) and then decline, followed by IgG antibodies, which increase within the first three weeks and persist in the blood for long periods of time (Adams et al., 2020; Lou et al., 2020; Ni et al., 2020; Okba et al., 2020; Padoan et al., 2020; Bartsch et al., 2021). Similarly, asymptomatic individuals rapidly seroconverted after SARSCoV-2 infection, with elicitation of primarily IgG antibodies (Jiang et al., 2020) (Fig. 2B). Antibody responses mainly target $\mathrm{S}$ and $\mathrm{N}$ proteins, and S-specific IgG levels were shown to correlate with neutralization (Okba et al., 2020). In two studies, serum IgG levels were found to rapidly decay 2-3 months postinfection in asymptomatic or mild COVID19 patients, raising concerns about the duration of immunity (Ibarrondo et al., 2020; Long et al., 2020). On the contrary, persistence of IgG was longer, beyond three months, in other studies assessing patients with 
moderate or severe disease (Isho et al., 2020; Iyer et al., 2020; Wajnberg et al., 2020). Importantly, disease severity was associated with earlier seroconversion and higher antibody titers, a phenomenon observed both for SARS-CoV-2 and MERS-CoV (Ko et al., 2017; Wang et al., 2020c). This evidence could imply a role of virusspecific antibodies in the worsening of the disease, a phenomenon known as antibody-dependent enhancement (ADE), previously described for respiratory syncytial virus (RSV) infection and occurring in vitro in SARS-CoV-1 experiments. However, current clinical data are insufficient to implicate ADE in COVID-19 (Arvin et al., 2020; Graham, 2020).

Strong evidence of viral neutralization by S-specific IgG and the need for quick remedies for COVID-19 patients while vaccines were still in development led to a focus on the isolation of monoclonal antibodies (mAbs) from COVID-19 convalescent patients (Cohen, 2020). Several research groups deployed state-of-theart technologies that were rapidly adapted from the human immunodeficiency virus (HIV), RSV, and Ebola research fields (Cohen, 2020). Indeed, several potent mAbs were isolated against the S protein, most of them targeting the RBD domain, which help defining critical characteristics of antibody-mediated protection to SARSCoV-2 (Barnes et al., 2020a; Barnes et al., 2020b; Baum et al., 2020b; Brouwer et al., 2020; Hansen et al., 2020; Ju et al., 2020; Piccoli et al., 2020; Pinto et al., 2020; Tortorici et al., 2020; Wang et al., 2020a; Wu et al., 2020b; Andreano et al., 2021). Additional studies determined that the IgG heavy-chain variable region 3-53 (VH3-53) was used most frequently among RBD-targeting antibodies (Barnes et al., 2020a; Yuan et al., 2020). These antibodies, defined as class 1 , represent a public antibody response to the RBD epitope in the "up" conformation, which mediates binding to the ACE2 receptor. Class 2 antibodies exhibit more diverse $\mathrm{VH}$-gene usage and bind the RBD in both "up" and "down" conformations. A second $\mathrm{S}$ protein neutralization target, the N-terminal domain (NTD), was less immunogenic than RBD, possibly due to extensive glycosylation (Chi et al., 2020; Piccoli et al., 2020; Rogers et al., 2020; Sun et al., 2020a; Walls et al., 2020b; GSK, 2021). Potent human neutralizing antibodies were also isolated against the NTD "i" supersite, displaying similar potency to RBD-directed mAbs (McCallum et al., 2021). More recent data indicate that the convalescent plasma IgG response to SARS-CoV-2 is directed overwhelmingly toward non-RBD epitopes, including potently neutralizing antibodies against the NTD (Voss et al., 2021). Importantly, given the constant selective pressure on the RBD and the NTD domains by the immune system, SARS-CoV-2 variants of concern emerged, harboring frequent mutations in these two sites, as described below.
The functionality of potent neutralizing mAbs was demonstrated in animals, primarily rodents and nonhuman primates (NHPs), which were protected from SARS-CoV-2 infection after mAb injection (Baum et al., 2020a; Hansen et al., 2020; Rogers et al., 2020; Tortorici et al., 2020; Zost et al., 2020; Jones et al., 2021). Importantly, a strong correlation between neutralizing antibodies and reduction of viral load was determined in NHPs (Guebre-Xabier et al., 2020; Mercado et al., 2020; van Doremalen et al., 2020; Zost et al., 2020; Jones et al., 2021). Aside from mechanistically blocking viral cell entry, animal studies indicated that effector functions mediated by the antibody Fc domain (i.e., antibody-dependent cellular cytotoxicity, phagocytosis, and cell recruitment) contributed to optimal protection against SARS-CoV-2 (Schafer et al., 2021; Winkler et al., 2021).

In humans, transfusion of hyperimmune plasma with high titers of neutralizing antibodies from convalescent persons to hospitalized patients was initially considered for early COVID-19 therapy (Liu et al., 2020a). Several studies have reported some level of benefit for plasma therapy; however, due to the complexity and risks linked to this practice, attention was shifted to the isolation and use of human mAbs (Renn et al., 2020; Katz, 2021). The use of mAbs demonstrated efficacy in preventing disease progression of outpatients with COVID-19 and enhancing viral clearance (Celltrion, 2021; Chen et al., 2021a; Weinreich et al., 2021) (Eom et al., preprint, https://www. researchsquare.com/article/rs-296518/v1). This evidence supported the Emergency Use Authorization (EUA) of bamlanivimab (AbCellera/Eli Lilly; combination of LY-CoV555 with etesevimab LY-CoV016) and REGN-COV2 (Regeneron; a combination of two mAbs, casirivimab REGN10933 and imdevimab REGN10987) by the U.S. Food and Drug Administration (FDA), and the approval of regdanvimab (Celltrion; monotherapy with CT-P59 mAb) by the European Medicines Agency; several other mAbs are in clinical development (Taylor et al., 2021). Sotrovimab (Vir Biotechnology/GSK; VIR-7831) is a mAb isolated from a 2003 SARS-CoV-1 survivor, targeting the RBD glycan N343 that is highly conserved among Sarbecoviruses. N343 is distinct from the receptor-binding motif, thus not competing for ACE2 binding in solution (Pinto et al., 2020) (Cathcart et al., preprint, https://www.biorxiv.org/content/10.1101/ 2021.03.09.434607v1). VIR-7831 has received EUA (U. S. Food and Drug Administration, 2021a) after the evidence of profound efficacy ( $85 \%$ reduction in hospitalization or death) in phase 3 clinical trial (GSK, 2021). Studies are now expanding to determine whether mAbs could be used to prevent SARS-CoV-2 infection and as an alternative to vaccination for people who cannot take vaccines, are immunodeficient, need 
more immediate prophylaxis, or as a rapid postexposure treatment (Cohen, 2021b).

After the extensive analysis of neutralizing immunity to the $\mathrm{S}$ protein, studies evaluating the antibody response to other SARS-CoV-2 antigens were conducted but did not provide compelling evidence of neutralizing immunity.

The $\mathrm{N}$ antigen is a highly abundant and immunogenic protein expressed during viral replication, which participates in RNA transcription, amplification, and packaging into virions (Chang et al., 2006; Sariol and Perlman, 2020). It is the target of both antibodies and $\mathrm{T}$ cells, responsible for virus clearance in SARS-CoV-1 infections in mice (Zhao et al., 2010) and of SARS-CoV-2-specific CD8+ and CD4+ T cells in humans (Grifoni et al., 2020). Prior SARSCoV-1 immunogenicity studies demonstrated that active immunization could elicit both $\mathrm{CD} 4+$ and $\mathrm{CD} 8+\mathrm{T}$ cell responses in mice (Liu et al., 2006). However, N-specific immune serum did not protect mice against SARS-CoV-2 infection (Sun et al., $2020 \mathrm{~b}$ ). Thus, the $\mathrm{N}$ protein is regarded as a target for viral clearance.

The $\mathrm{M}$ and $\mathrm{E}$ proteins are required for virus assembly (Schoeman and Fielding, 2019). Due to their small ectodomain, they are poorly immunogenic ( $\mathrm{Du}$ et al., 2008). In mice, sera elicited against $M$ or $E$ protein did not protect against SARS-CoV-2 infection (Sun et al., 2020b).

\section{B. T Cell Responses}

$\mathrm{T}$ cell responses are often neglected when studying viruses as it is generally assumed antibodies are necessary for virus neutralization. However, they play an important role for B cell maturation, antibody production, and viral clearance. In COVID-19 patients, virus-specific $\mathrm{CD} 4+$ and $\mathrm{CD} 8+\mathrm{T}$ cell responses were associated with mild disease, suggesting the potential of cellular immunity in protecting against SARS-CoV-2 (Peng et al., 2020; Rydyznski Moderbacher et al., 2020; Tan et al., 2021). Indeed, an ideal vaccine would be expected to elicit both humoral and cellular immune responses. Using peptide pools, several studies showed that CD4 + T cell responses were primarily directed to $\mathrm{M}, \mathrm{N}$, and S proteins and, to a lesser extent, to nonstructural viral proteins, suggesting a broad reactivity against multiple viral targets (Grifoni et al., 2020; Le Bert et al., 2020; Peng et al., 2020; Nelde et al., 2021). Low and colleagues reported that $34 \%$ T cell clones from 34 COVID-19-recovered individuals recognized a conserved immunodominant region within the RBD (Low et al., 2021). Virus-specific CD4 + T cells were also present in $40 \%-60 \%$ healthy controls, reflecting a certain degree of crossreactivity with pre-existing coronavirus immunity (Grifoni et al., 2020; Le Bert et al., 2020; Nelde et al., 2021).
The $\mathrm{S}$ protein was a main target of $\mathrm{CD} 8+\mathrm{T}$ cell responses (Grifoni et al., 2020). These findings were in line with another study which detected robust virus-specific $\mathrm{T}$ cells activated in acute COVID-19 and in $28 \%$ of unexposed healthy donors (Sekine et al., 2020). Crossreactivity to seasonal coronavirus and other viruses could affect vaccination outcomes, leading to a faster or better immune response, or might be detrimental, through mechanisms of dampening of the de novo immune response ("original antigenic sin") or via ADE of disease, and require to be further investigated (Sette and Crotty, 2020).

\section{Vaccine-Elicited Immunity}

\section{A. Overview on SARS-CoV-2 Vaccines}

After the global spread of SARS-CoV-2, it quickly became apparent that stopping the pandemic and achieving herd immunity could only be accomplished via vaccination. Employing technologies and lessons learned from other infectious diseases such as HIV, influenza, RSV, and Ebola, a globe-spanning effort was launched to develop efficacious SARS-CoV-2 vaccines with overlapping-rather than sequentiallynonclinical and clinical studies that ensured fast development without compromising on safety and quality (Kelley, 2020; Rappuoli et al., 2021). Considering the scale of the pandemic, researchers agreed that several vaccines would need to be developed in parallel to facilitate the production and distribution of billions of vaccine doses. To address this significant challenge, diverse vaccine types, including inactivated/attenuated virus vaccines, nucleic acid-based vaccines, nonreplicating vector, and recombinant subunit vaccines, underwent rapid development. The general description of these different approaches is detailed in several reviews (Dong et al., 2020; Krammer, 2020; Dai and Gao, 2021). In the following sections, we will focus on the immunogenicity and efficacy against COVID-19 of the most advanced SARS-CoV-2 vaccines (approved for use or in phase 3 clinical trials).

The development of these vaccines was incredibly rapid, with some being approved by regulators for emergency use in less than one calendar year from the onset of the pandemic, thanks to unprecedented levels of international collaborations, funding, data sharing, and use of synthetic gene expression technologies. One of the key accelerators was the complete and open access to the viral genome sequences that facilitated viral spread monitoring and the design of diagnostic tests and vaccine candidates. The development of vaccines and treatments for other coronaviruses provided the basis for the development of SARS-CoV-2 vaccines (Park et al., 2020; Sariol and 
Pecetta et al.

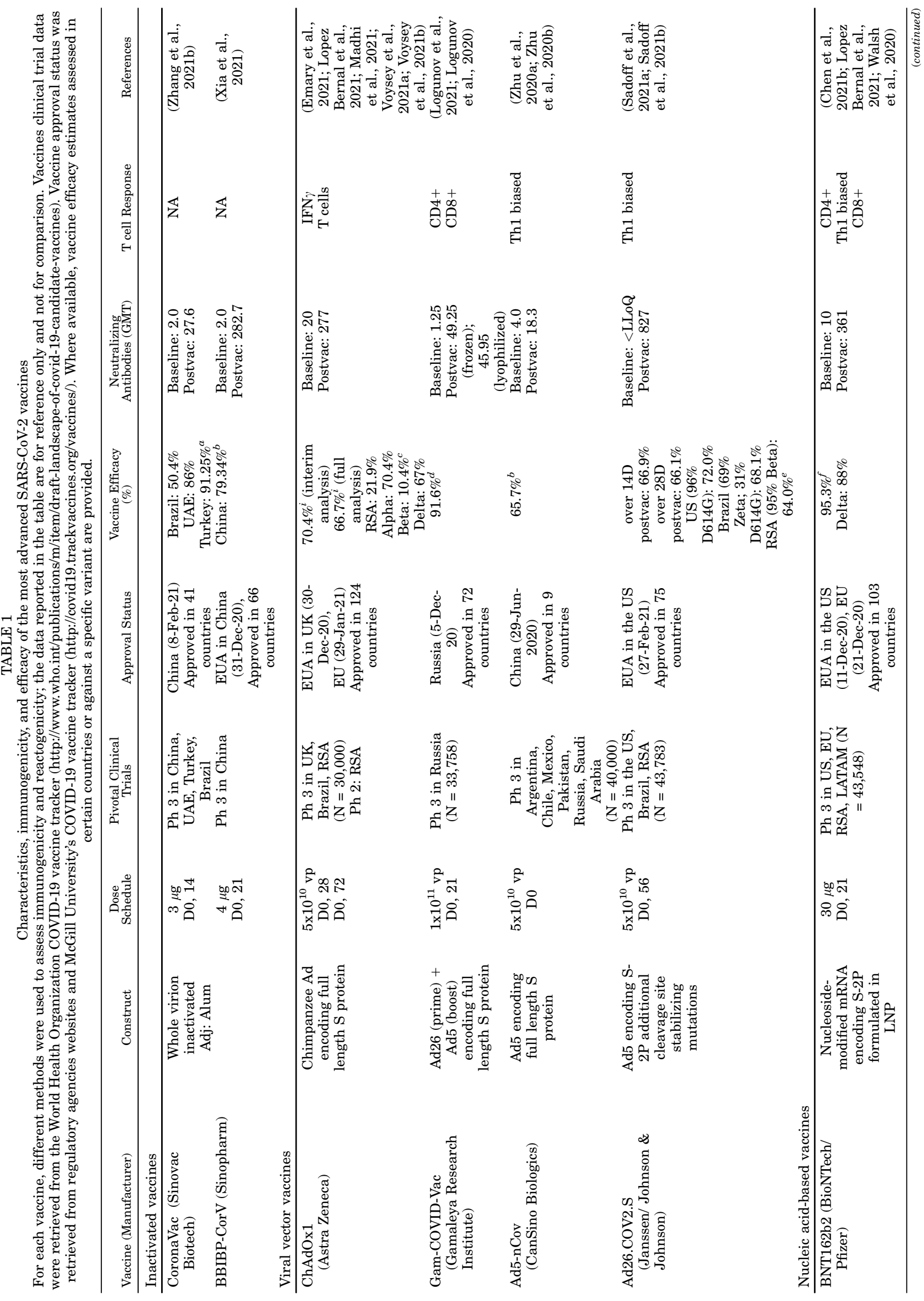




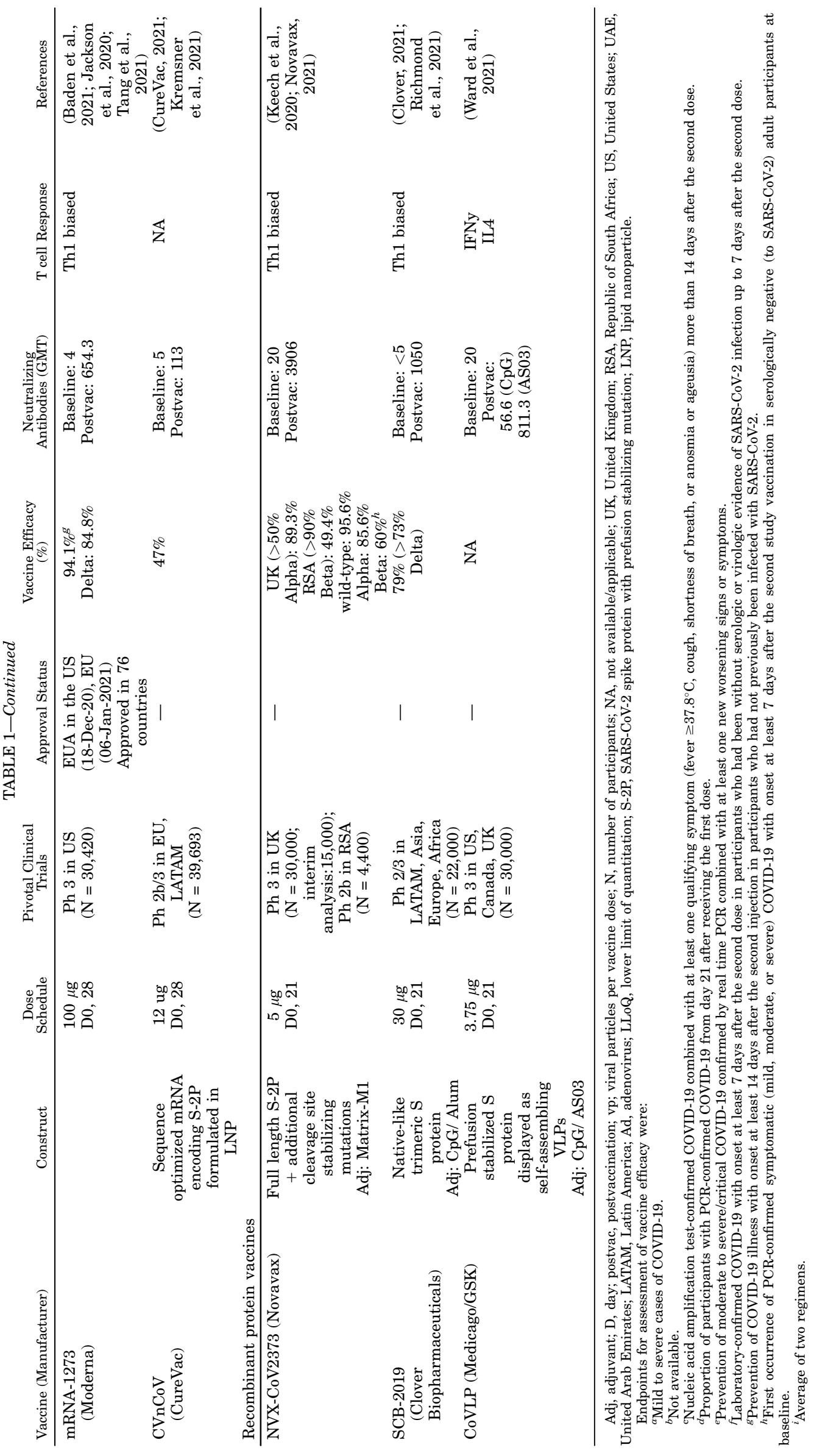


Perlman, 2020). However, prior to the COVID-19 pandemic, no coronavirus vaccine was approved for human use, with the most advanced SARS-CoV-1 and MERS-CoV candidates still in phase 1 clinical trial (NCT00099463, NCT03399578, NCT04170829) (Li et al., 2020b; Tizard, 2020). Nonetheless, instrumental to the success of new SARS-CoV-2 vaccines were previous findings from structural vaccinology studies that identified key amino acid substitutions for stabilizing the RSV viral fusion protein in its prefusion conformation, which is considered highly important for the induction of functional neutralizing antibodies (McLellan et al., 2013a; McLellan et al., 2013b). Structure-based design was previously used to stabilize the MERS-CoV spike protein as well, which elicited more potent antibody responses (Pallesen et al., 2017). Learnings from these studies were eventually applied to the SARS-CoV-2 S protein, resulting in a $\mathrm{S}-2 \mathrm{P}$ antigen bearing two proline substitutions that stabilize the protein in the prefusion conformation, the antigen of choice for some of the most advanced vaccines (Wrapp et al., 2020). In addition to structural vaccinology approaches, reverse vaccinology, synthetic biology, and platform technologies were also instrumental in the accelerated development of SARS-CoV-2 vaccines (Rappuoli et al., 2021). A considerable amount of research was focused on the design of gene-based vaccines. In oncology, research on synthetic gene delivery contributed for decades to the development of therapies allowing gene transfer to repair nonfunctional alleles (Anguela and High, 2019). In the infectious disease space, transfer of DNA encoding viral antigen and viral RNA delivery via lipid nanoparticles were previously developed for vaccination (Martinon et al., 1993; Ulmer et al., 1993). The synthetic gene delivery approach obviates the need for expressing large quantities of viral proteins required for immunization; however, this had never been tested beyond phase 2 and never on a global population level. Evidence on genebased vaccines in humans was accumulated for the first time during the COVID-19 pandemic.

\section{B. Immunogenicity and Efficacy of the Different Vaccine Platforms Targeting Spike Protein}

Even though most vaccines incorporate the viral $\mathrm{S}$ protein as the primary target of the immune system, the use of different technologies resulted in marked differences in terms of level of spike-specific immunity and vaccine efficacy against COVID-19 (summarized in Table 1).

1. Inactivated and Attenuated SARS-CoV-2 Vaccines. Virus inactivation is an established and relatively easy approach for producing stable vaccines, which has contributed to the near eradication of polio and prevention of other diseases. A drawback for inactivated vaccines against COVID-19 is that biosafety level 3 containment facilities are required to grow the live virus (World Health Organization, 2020a), which limits manufacturing capability.

To face the COVID-19 pandemic, vaccines based on inactivated SARS-CoV-2 virus were readily developed and BBIBP-CorV (Sinopharm) and CoronaVac (Sinovac Biotech) were approved for human use. The immunogenicity of BBIBP-CorV was first tested in animals including rodents and NHPs. Two $2 \mu \mathrm{g} / \mathrm{dose}$ immunizations with BBIBP-CorV provided protection against SARS-CoV-2 challenge in NHPs (Wang et al., 2020b). In humans, BBIBP-CorV was safe and well tolerated in a phase $1 / 2$ study conducted in China, with mild or moderate adverse reactions in $23 \%$ of participants (76/336 in phase 2) and no reported serious adverse events (Xia et al., 2021). Vaccine-elicited neutralizing antibody titers were highest with two $4 \mu \mathrm{g}$ doses set 21 days apart, with a geometric mean titer (GMT) of 282.7 at 28 days postsecond dose. Convalescent neutralizing levels were not reported for comparison. CoronaVac had a similar safety profile in phase $1 / 2$ clinical trials, with detection of any adverse reactions in $33 \%$ of participants (40/120 in phase 2$)$ for the 0, 14-day $3 \mu \mathrm{g} /$ dose schedule (Zhang et al., 2021b). The GMT of neutralizing antibodies for this cohort was 27.6, compared with 163.7 in convalescent asymptomatic patients. To this date, vaccine efficacy in phase 3 trials in China, United Arab Emirates, Turkey, and Brazil was reported to be between 50\% and $91 \%$ for BBIBP-CorV and CoronaVac (Kim et al., 2021; Tanriover et al., 2021).

BBV152 (Covaxin, Bharat Biotech) was evaluated in a phase 2 trial in adults and adolescents 12-65 years of age in India receiving 3 and $6 \mu \mathrm{g}$ doses administered 28 days apart. The first results of the study indicate that at four weeks postvaccination, GMTs of neutralizing antibodies were higher in the $6 \mu \mathrm{g}$ group and comparable to those in convalescent patients. Both formulations were well tolerated, with around $40 \%$ of participants experiencing solicited adverse events and no serious adverse events reported (Ella et al., 2021). Another inactivated vaccine, PiCoVacc (Sinovac Biotech) was immunogenic and safe in animal models and showed protection against SARSCoV-2 challenge in macaques (Gao et al., 2020).

Live-attenuated SARS-CoV-2 vaccines were evaluated in preclinical studies. YF-SO, composed of a yellow fever virus 17D backbone expressing SARS-CoV-2 spike protein, induced protective immunity in hamsters and macaques after one dose (Sanchez-Felipe et al., 2021).

Traditionally, inactivated vaccines are stable at refrigerator temperature $\left(2-8^{\circ} \mathrm{C}\right)$ and affordable, making them particularly suitable for developing countries, and they are therefore the target of a considerable part of the SARS-CoV-2 vaccine effort. However, weakly neutralizing titers and Th2-skewed responses associated 
with inactivated vaccines warrant further investigation and close follow-up in case of emergence of viral variants (Jeyanathan et al., 2020).

2. Viral Vector SARS-CoV-2 Vaccines. Multiple replication incompetent vector vaccines carrying the SARS-CoV-2 S protein have been licensed in several countries for human use. Vectored vaccines attract the immune system's attention to the viral protein without the need of adjuvants. However, pre-existing and newly elicited vector specific immunity can result in the blunting of immunogenicity, thus, lowering the efficacy of the vaccine. To address this, researchers have employed modified vectors from viruses less common in humans or adapted from other species. Adenoviruses have been studied for almost two decades as vehicles for HIV, malaria, influenza, Ebola, and tuberculosis antigens (Zhang and Zhou, 2016).

CanSino Biologics and Beijing Institute of Biotechnology developed an adenovirus type 5 vectored SARSCoV-2 vaccine (Ad5-nCov; Convidecia). In phase 1/2 studies conducted in China, the vaccine elicited neutralizing antibodies (GMT of 18.3) and specific T cell responses with a single-dose regimen of $5 \times 10^{10}$ viral particles. For this regimen, solicited adverse reactions were reported by $74 \%$ participants (96/129 in phase 2) (Zhu et al., 2020a; Zhu et al., 2020b). Based on an interim analysis of the phase 3 trial, vaccine efficacy was reported in a press release to be $65.3 \%$ at preventing symptomatic COVID-19 (CanSino, 2021).

A similar strategy, with a recombinant adenovirus type 26 encoding a full-length prefusion stabilized SARS-CoV-2 S protein (Ad26.COV2.S) was employed by Janssen/Johnson \& Johnson. This is the only vaccine currently employed that is administered as a single dose. Ad26 vector was previously used to deliver the Ebola vaccine Ad26.ZEBOV approved for human use, in combination with a modified vaccinia Ankara vector (Pollard et al., 2021). Immunization with Ad26.COV2.S induced robust neutralizing antibody responses and provided complete protection from SARS-CoV-2 challenge in NHPs, with almost no detectable virus in the lungs and nose (Mercado et al., 2020). In humans, a $5 \times 10^{10}$ viral particles dose resulted in a neutralizing antibody GMT of 288 , which increased to 827 after a boost at eight weeks (Sadoff et al., 2021b). In phase 3 trials, worldwide efficacy was $66.1 \%$ against moderate to severe COVID-19 (at $\geq 28$ days postvaccination), with vaccinees reporting primarily local reactions, whereas serious adverse events occurred in $0.4 \%$ of vaccinated individuals, comparable to the placebo group (Sadoff et al., 2021a).

In contrast, a heterologous prime-boost approach of recombinant adenovirus type $26(\mathrm{rAd} 26-\mathrm{S})$ and type 5 (rAd5-S), both carrying the SARS-CoV-2 S protein gene, was developed by Gamaleya Research Institute of Moscow (Gam-COVID-Vac, Sputnik-V). In phase
1/2 studies, heterologous prime-boosting with GamCOVID-Vac elicited strong humoral responses with neutralizing antibody titers of 49.25 , which was comparable to titers measured in convalescent plasma. The vaccine also induced antigen-specific CD4+ and $\mathrm{CD} 8+\mathrm{T}$ cells cellular immune responses (Logunov et al., 2020). The efficacy against polymerase chain reaction (PCR)-confirmed COVID-19 from three weeks after receiving the first vaccine dose was reported to be $91.6 \%$ in an interim analysis of phase 3 data (Logunov et al., 2021).

Simian adenovirus was used to develop the ChAdOx1 vaccine (AZD1222, Covishield/Vaxzevria) by Oxford University and AstraZeneca. The ChAdOx1 vector was previously used to develop, among other candidates, a malaria vaccine that reached phase $1 / 2$ clinical testing (NCT03203421). Optimal dosing for the COVID19 vaccine has been the subject of extensive investigations. In a phase $1 / 2$ trial, median neutralizing titers were higher after the second dose (87.9 after one dose, 162.9 after two doses), and similar to the ones observed in convalescent plasma from patients recovered from COVID-19 (Folegatti et al., 2020). A second dose of ChAdOx1 correlated with enhanced Fc-mediated functional antibody responses (Barrett et al., 2021). In the interim analysis of the pivotal phase 3 clinical trial conducted in the United Kingdom, Brazil, and South Africa, vaccine efficacy against laboratory-confirmed, symptomatic COVID-19 more than 14 days after the second dose was $62.1 \%$ in participants who received two standard doses and was $90 \%$ when a half-dose was followed by a full dose after at least one month. Overall vaccine efficacy across both groups was $70.4 \%$ (Voysey et al., 2021a). A subsequent pooled analysis from the same trial suggested that allowing longer time between doses, a feature of the latter subgroup, was more important than lowering the priming dose (Voysey et al., 2021b). Indeed, since its EUA, vaccine administration was conducted 4-12 weeks apart, with the World Health Organization (WHO) recommended interval of 8-12 weeks (World Health Organization, 2021b). Longer prime-boost intervals increased spike-specific IgG levels and vaccine effectiveness, reaching $81.3 \%$ in case of an interval of 12 weeks or more versus $55.1 \%$ for an interval of less than six weeks (Voysey et al., 2021b). Among controversies on data analysis of a subsequent phase 3 trial in the US, Peru, and Chile, which included two doses administered four weeks apart, preliminary assessment marked the efficacy at $76 \%$ at preventing PCR-confirmed, symptomatic COVID-19 and $100 \%$ at preventing severe disease. Notably, efficacy was higher in older individuals, 65 and over (AstraZeneca, 2021). Even though no major safety concerns were raised during clinical development, adenovirus-based vaccines were associated with very rare thrombotic thrombocytopenia events, resulting in public concern (Ledford, 2021). From an immunologic standpoint, these rare events could be associated to 
development of antiplatelet factor 4 antibodies, although further research is required to fully understand this phenomenon (Greinacher et al., 2021).

Replication competent viruses have been tested in preclinical studies but had not reached clinical stage yet. A vesicular stomatitis virus vaccine expressing a modified form of the $\mathrm{S}$ protein (VSV-eGFP-SARSCoV-2) elicited high antibody titers and reduced viral infection and lung inflammation after challenge in mice, indicating protection against COVID-19 (Case et al., 2020). Similarly, the vesicular stomatitis virusvectored vaccine ConVac expressing SARS-CoV-2 S1 subunit demonstrated protection against severe COVID-19 in hamsters (Malherbe et al., 2021).

3. Nucleic Acid SARS-CoV-2 Vaccines. Vaccines based on mRNA have shown great promise and were the first to be authorized for human use by the FDA and European Medicines Agency. Extremely fast in vitro production of these vaccines was essential to achieve the rapid scale-up that brought them to the clinics in less than 6 months. Moreover, recent advances in RNA nucleoside modification, technological improvement for in vivo delivery, and spike-stabilizing mutations, described before, have greatly enhanced their immunogenicity (Chaudhary et al., 2021). Particularly, engineering of the RNA sequence, including codon optimization, capping and tail regulatory sequences modification, and the use of immunosilent nucleosides such as pseudouridine and 1-methylpseudouridine, greatly enhanced stability and level of protein expression (Pardi et al., 2018). Vaccines developed by Moderna (mRNA-1273; Moderna COVID-19 vaccine) and BioNTech/Pfizer (BNT162b2; Comirnaty), based on sequence optimized nucleoside-modified mRNAs formulated in lipid nanoparticles, received EUA in December 2020. BNT162b2 became the first FDA-approved vaccine for the prevention of COVID-19 disease in individuals 16 years of age and older (Food and Drug Administration, 2021b). In the case of mRNA-1273, the EUA allows vaccination of individuals 18 years of age and older.

Moderna's mRNA-1273, jointly developed with the National Institutes of Health, was first demonstrated to be immunogenic and protective in NHPs, which received two doses of 10 or $100 \mu \mathrm{g}$ four weeks apart (Corbett et al., 2020). In a phase 1 study, participants were immunized with either 25,100 , or $250 \mu \mathrm{g}$ mRNA-1273 at 28 days apart (Jackson et al., 2020). Serum neutralizing titers were highest after two $100 \mu \mathrm{g}$ doses (GMT of 654.3), and in the upper range of the neutralization response observed in convalescent samples. $\mathrm{T}$ cell responses were biased toward Th1 cytokines. In a follow-up study, vaccine immunogenicity in the elderly was assessed, with high neutralizing antibody titers detected in both the age groups 56-70 and 71 and older (GMTs of 402 and 317, respectively) (Anderson et al., 2020). Phase 3 data from a trial conducted in the United States and using the $100 \mu \mathrm{g}$ dosage showed a vaccine efficacy of $94.1 \%$ against COVID-19 illness with onset at least 14 days after the second vaccine dose (Baden et al., 2021).

During the development of the Pfizer/BioNTech vaccine, two sets of mRNA vaccines coding either for the RBD-only domain (BNT162b1) or full-length S protein (BNT162b2) were initially evaluated. Findings from phase 1 studies showed that two consecutive $30 \mu \mathrm{g}$ doses of BNT162b1/2 elicited high SARS-CoV-2 neutralizing antibody titers and robust levels of antigen-specific CD8+ and Th1-type CD4+ T-cell responses (Mulligan et al., 2020; Sahin et al., 2020; Walsh et al., 2020). Both vaccines elicited dose-dependent SARSCoV-2 neutralizing antibody titers (GMTs of 437 for BNT162b1 and 163 for BNT162b2 at 14 days postsecond dose for the $30 \mu \mathrm{g}$ doses, in participants 18-55 years of age), although BNT162b2 was less reactogenic, probably due to a lower number of mRNA copies in the formulation. These neutralizing antibody GMTs were 1.7 to 4.6 times higher than the average neutralizing response of convalescent serum. Analysis of phase 3 clinical trials showed a vaccine efficacy of $95.0 \%$ against laboratory-confirmed COVID-19 with onset at least 7 days after the second dose for BNT162b2 (Polack et al., 2020). In a subsequent clinical trial designed to assess protection of adolescents 12-15 years of age, which are particularly exposed to the virus due to in-person learning and socialization, vaccine efficacy was $100 \%$ (Frenck et al., 2021).

After the beginning of the mass vaccination campaign in Israel, real-world vaccine effectiveness of 97.0\% against symptomatic COVID-19 was observed between January 24 and April 3, 2021 (Haas et al., 2021). In the United States, vaccine effectiveness was reported to be $88.8 \%$ and $96.3 \%$ for BNT162b2 and mRNA-1273, respectively (Pilishvili et al., 2021).

A third mRNA vaccine, $\mathrm{CVnCoV} \mathrm{(CureVac),} \mathrm{com-}$ posed of nonmodified codon-optimized mRNA encoding for prefusion stabilized S protein, was recently assessed in a pivotal phase $2 \mathrm{~b} / 3$ trial after positive phase 1 data demonstrating induction of high neutralizing titers with two $12 \mu \mathrm{g}$ vaccine doses administered 28 days apart (Kremsner et al., 2021). However, the phase $2 \mathrm{~b} / 3$ study reported a vaccine efficacy of $47 \%$ against COVID-19 of any severity across all age groups, markedly lower than the other mRNA vaccines (CureVac, 2021). This study was conducted in the context of a high prevalence of SARS-CoV-2 variant strains and an almost complete absence of the wild-type virus (see section V.B).

Despite being the product of a relatively new technology that had never before been tested in a large population, all mRNA COVID-19 vaccines demonstrated a high safety profile both in clinical trials and in real-world settings. After a mass vaccination 
campaign in more than 2.4 million people, BNT162b2 vaccination was reported not to be associated with an elevated risk of most of the adverse events examined, except for a possible excess risk of myocarditis (1-5 events per 100,000 persons) (Barda et al., 2021). The latter evidence calls for the need of further studies to better estimate long-term effects of this class of vaccines.

DNA vaccines are also being developed against SARS-CoV-2, although not yet approved for human use. DNA vaccines need to be delivered into cell nuclei, so they require particular type of injection devices. INO-4800 (Inovio Pharmaceuticals), AG0301 (AnGes and Takara Bio), and ZyCoV-D (Zydus Cadila) are currently in phase $2 / 3$ trials. In phase 1 , INO4800 elicited neutralizing antibodies in $78 \%$ and $84 \%$ of participants when electroporated at two $1 \mathrm{mg}$ and 2 mg doses, respectively; GMTs were 102.3 and 63.5 for the respective groups (Tebas et al., 2021).

4. Recombinant Protein SARS-CoV-2 Vaccines.

Recombinant spike-protein-based vaccines, recombinant RBD-based vaccines and viruslike particle (VLP)-based vaccines are currently under clinical investigation. As previously mentioned, the development process for these vaccines is more complex and time consuming, but well-known adjuvants can be used to boost the immune response. Adjuvants are vaccine components able to enhance magnitude, breadth, and durability of the immune response (Del Giudice et al., 2018; Pulendran et al., 2021).

NVX-CoV2373 (Covovax, Novavax) is a proteinbased vaccine candidate composed of the SARS-CoV-2 $\mathrm{S}$ protein and the saponin-based Matrix-M adjuvant. After intranasal and intratracheal challenge with SARS-CoV-2, macaques were protected against upper and lower infection and pulmonary disease when immunized with two 5 or $25 \mu \mathrm{g}$ doses of NVXCoV2373 (Guebre-Xabier et al., 2020). In phase 1/2 trials, NVX-CoV2373 elicited immune responses that exceed levels in COVID-19 convalescent serum (Keech et al., 2020). Two $5 \mu \mathrm{g}$ vaccine doses induced a neutralizing antibody GMT of 3906, four times higher than the one detected in symptomatic COVID-19 outpatients (837) and comparable to levels observed in hospitalized patients (7457) (Keech et al., 2020). In this clinical study, Matrix-M1-adjuvanted regimens induced antigen-specific $\mathrm{T}$ cell responses with a strong bias toward Th1 phenotype. Mild reactogenicity to the vaccine, more pronounced at the second dose, was consistent with previous experience with adjuvanted vaccines.

Other recombinant protein vaccine candidates are being developed. The SARS-CoV-2 prefusion stabilized $\mathrm{S}$ protein vaccine CoVLP (Medicago/GSK), expressed as VLPs produced in plant cells (Nicotiana benthamiana), elicited neutralizing antibody titers comparable to or 10 times higher than COVID-19 convalescents when adjuvanted with CpG1018 or AS03, respectively, and it is currently in phase $2 / 3$ trial (NCT04636697) (Ward et al., 2021). Another protein-based vaccine, developed by Sanofi/GSK and containing AS03-adjuvanted soluble S-2P trimer, showed preliminary positive results in NHPs using a refined formulation after the first one elicited an insufficient immune response in older adults, likely due to an insufficient concentration of the antigen (Francica et al., 2021; Goepfert et al., 2021). In a phase 2 trial, strong rates of neutralizing antibody response in all age groups (18-95 years old) were reported for all two-dose regimens used (antigen dose levels of 5, 10, and $15 \mu \mathrm{g}$ ) (Sanofi, 2021). This vaccine candidate is currently in phase 3 trial (VAT00008/ NCT04904549). Lastly, SCB-2019 native trimeric S protein (Clover Biopharmaceuticals) was tested at three different dosages $(3,9$, and $30 \mu \mathrm{g})$, administered as two doses 21 days apart using AS03, CpG/Alum, or no adjuvant formulations. Neutralizing antibody GMTs were 3948 and 1050 for the AS03 and the CpG/Alum groups at 36 days after the second $30 \mu \mathrm{g}$ dose and, respectively, 1522 and 1159 at 50 days in 18-54 years of age (Richmond et al., 2021). The frequency of local and general adverse events was higher in the AS03 group ( $\leq 75 \%$ and $\leq 62.5 \%)$ compared with CpG/Alum $(\leq 62.5 \%$ and $\leq 37.5 \%$ after each dose). Based on these results, a phase $2 / 3$ clinical trial with a $40 \mu \mathrm{g}$ dose plus $\mathrm{CpG} /$ Alum adjuvant was conducted, reporting an efficacy of $79 \%$ against COVID-19 and 100\% against severe disease, in a context where all sequenced strains were variants, mostly (73\%) Delta (Clover, 2021) (see section V.B).

Self-assembling protein nanoparticles, which have been shown previously to significantly improve potency and breadth of antibody response (Brouwer et al., 2019; Marcandalli et al., 2019), have also been used as templates for the design of SARS-CoV-2 vaccines. The two-component I53-50 nanoparticle, coming from studies in the HIV field, was used to display 60 RBDs in an array that elicited antibody titers 10 -fold higher than the prefusion-stabilized S protein despite a lower dose (Walls et al., 2020a).

\section{Vaccines Targeting Other SARS-CoV-2 Antigens}

Vaccines against SARS-CoV-2 have been mainly focused on the viral $\mathrm{S}$ protein due to the strong correlation between neutralization of viral entry and protection from disease. Due to low immunogenicity, the $\mathrm{M}$ and $\mathrm{E}$ proteins have not been identified as targets of vaccines. The highly immunogenic $\mathrm{N}$ protein was also not exploited as primary vaccine candidate. Th2-biased response and enhanced infection-induced pneumonia were observed in previous SARS-CoV-1 studies in N protein-immunized mice (Yasui et al., 2008). Moreover, $\mathrm{N}$ protein-directed antibodies were associated with COVID-19 immunopathology. High levels of IgG against $\mathrm{N}$ protein were associated with higher risk of admission to intensive care units (Batra et al., 2021). 
As reported in this study, the proposed mechanism behind this phenomenon is the generation of immune complexes on infected cells expressing $\mathrm{N}$ protein, resulting in proinflammatory cytokines and inflammation.

\section{SARS-CoV-2 Notable Variants}

\section{A. Emergence of SARS-CoV-2 Variants}

The first generation of COVID-19 vaccines was designed with the spike protein of the SARS-CoV-2 strain circulating during the early phases of the pandemic in 2020, Wuhan-Hu-1. During the course of the pandemic, several mutated lineages of SARS-CoV-2 emerged and abruptly spread globally (Fig. 4) (PANGO, 2021; World Health Organization, 2021c). A summary of terminology used to describe SARS-CoV-2 variants is reported in Fig. 5.

Compared with other RNA viruses like influenza or HIV, SARS-CoV-2 genome variation is slow to occur, probably because of a proofreading enzyme that corrects copying mistakes. Nonetheless, mutations arise at a rate of roughly 2 point mutations per month, and new variants can emerge via recombination between strains from different host species, including humans (Singh and Yi, 2021). Together with selective pressure by the immune system, this has given rise to numerous viral variants with concerning altered transmissibility that promptly activated monitoring of impact on immunity and disease severity (Koyama et al., 2020). Importantly, mutation speed does not change in the new variants, but the growing number of infected people increases the likelihood of even more variants to appear. In this paragraph, we report evidence related to notable variants that carry mutations implicated in immune evasion.

Amino acid substitution D614G in S1 subunit of the $\mathrm{S}$ protein of the original Wuhan-Hu-1 SARS-CoV-2 strain was the first to emerge in late January or early
February 2020 and became the dominant virus strain circulating globally by June 2020. Studies in human respiratory cells and animal models demonstrated that, compared with the original strain, D614G substitution enhanced virus transmission due to increased $\mathrm{S}$ protein shift toward a more ACE2-binding competent state (Korber et al., 2020; Yurkovetskiy et al., 2020; Ozono et al., 2021). Subsequently, in September 2020, a SARS-CoV-2 variant linked to infection in farmed mink was identified in Denmark, referred to as "Cluster 5" (World Health Organization, 2020b). There was concern that this variant could result in reduced virus neutralization in humans, but in the end it did not spread widely.

Starting with September 2020, in the United Kingdom, a cluster of viruses phylogenetically separated from the original viral strain was identified during continuous epidemiologic surveillance (Public Health England, 2020). This strain gave a negative result on the PCR targeting spike protein in a three-target test (S, ORF1ab, and N), suggesting the presence of multiple mutations in the viral receptor. This variant was initially termed "variant under investigation" VUI202012/01 and subsequently became "variant of concern" (VOC) 202012/01 or B.1.1.7 (WHO label Alpha) when it was demonstrated to spread more rapidly in the population, although no evidence of increased disease severity has been reported (Public Health England, 2020). Alpha spread quickly in the United Kingdom with a modeled increased transmissibility of 53\%-56\% (Davies et al., 2021; Volz et al., 2021) and being $43 \%-90 \%$ more transmissible than the previous lineage (Davies et al., 2021). Genome sequencing revealed a total of 23 mutations, including amino acid substitutions and deletion in the spike RBD domain (Fig. 6). Three mutations, N501Y, P681H, and H69V70 deletion were linked to increased ACE2 binding and potential escape from neutralizing antibodies. Particularly, N501Y was demonstrated to increase

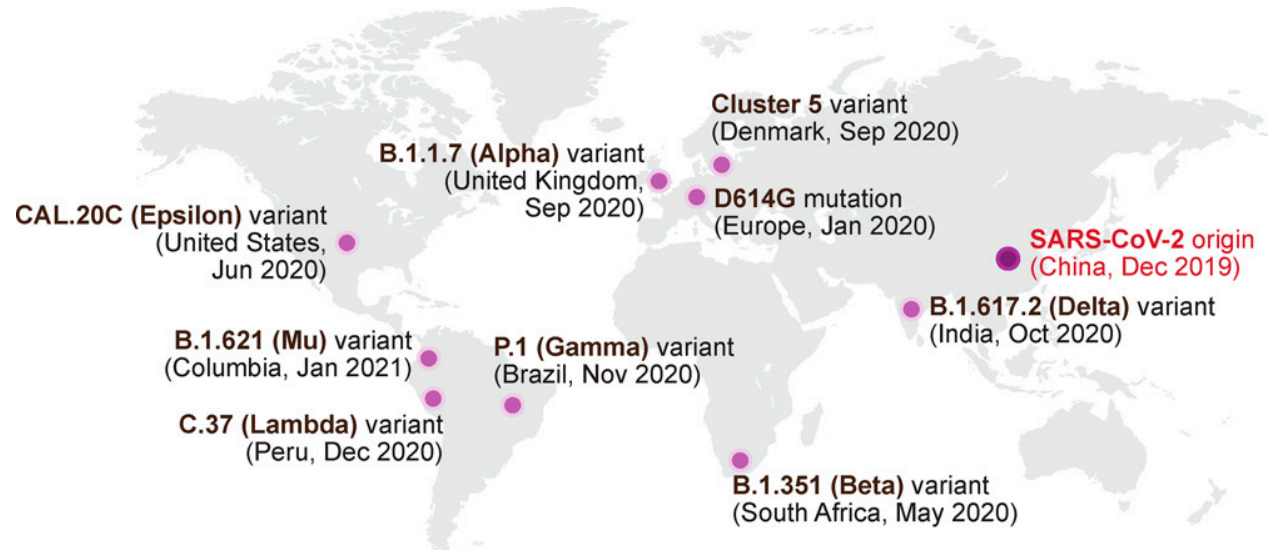

Fig. 4. Origin and timeline of appearance for notable SARS-CoV-2 variants. The origin of viral variants across the world and the date of their earliest documentation during the COVID-19 pandemic (World Health Organization, 2021c). 


\begin{tabular}{ll}
\hline Term & Description \\
\cline { 1 - 2 } Wild type & $\begin{array}{l}\text { The reference viral genetic sequence. } \\
\text { For SARS-CoV-2, this refers to the original Wuhan strain isolated in } 2020 .\end{array}$ \\
Variant & $\begin{array}{l}\text { A virus presenting a set of mutations in its genome that are selected } \\
\text { through numerous rounds of replication. }\end{array}$ \\
Lineage & $\begin{array}{l}\text { The positioning of the new variant on a distinct branch of the phylogenetic } \\
\text { tree which (for SARS-CoV-2) is associated with an epidemiological event. }\end{array}$ \\
Strain & $\begin{array}{l}\text { A virus that has accumulated mutations in its genome that produce } \\
\text { a distinct phenotype. }\end{array}$
\end{tabular}

Fig. 5. Terminology of SARS-CoV-2 variants. Brief description of the terminology used in the manuscript referred to SARS-CoV-2 virus (Rambaut et al., 2020; Mascola et al., 2021).

in vitro binding to ACE2-expressing cells (Starr et al., 2020).

In December 2020, national authorities in South Africa announced the spread of a new variant, named 501Y.V2 or B.1.351, and subsequently labeled as Beta by the WHO, which became dominant in the region and was eventually classified as VOC (Fig. 4) (Tegally et al., 2021a). During continuous genomic surveillance, several other SARS-CoV-2 variants were reported in South Africa (Tegally et al., 2021b). The Beta variant is characterized by eight lineage-defining mutations in the spike protein, including three substitutions of functional significance, K417N, E484K, and N501Y, as described below. Lineage P.1, also known as $20 \mathrm{~J} / 501 \mathrm{Y}$.V3 or the Gamma variant (first documented in November 2020), arose in Brazil in January 2021, causing widespread infection in Manaus, despite high seroprevalence (76\%) against the wild-type strain in the population (Faria et al., 2021; Sabino et al., 2021). Gamma has 17 unique amino acid changes and shares with Beta the acquisition of N501, K417, and E484 mutations, being now classified as VOC (Fig. 4). A separate study identified the P.2 (Zeta) lineage, which also harbors the spike E484K mutation but not the N501Y and K417T mutations, which concomitantly appeared in several locations in Brazil but evolved independently from the Gamma lineage from Manaus (Naveca et al., 2021).

Since its earliest detection in October 2020, variant B.1.617.2 or Delta has rapidly spread from India, and in less than a year, it became the dominant SARS$\mathrm{CoV}-2$ variant in circulation worldwide, outcompeting pre-existing lineages including Alpha. The B.1.617 lineage was initially identified as carrying two mutations that might be related to increased transmissibility and immune evasion: E484Q (similar to E484K substitution in South African and Brazilian strain) and L452R (found in the California variant CAL.20C [B.1.427/1.429], WHO label Epsilon) (Fig. 4) (Ferreira et al., 2021; Pattabiraman et al., 2021). One important feature of Delta was the significant replication advantage observed in vitro in comparison with
Alpha, both in human airway epithelial model and airway organoids (Mlcochova et al., 2021). Viral cell entry is dependent on the polybasic cleavage site between S1 and S2 (Peacock et al., 2021). The Alpha spike bearing the $\mathrm{P} 681 \mathrm{H}$ mutation was reported to have significantly higher fusogenic potential than a D614G Wuhan virus, which resulted in increased spike-mediated cell entry (Meng et al., 2021). Similarly, mutation P681R in the B.1.617 spike was linked with a higher portion of cleaved spike compared with Alpha and increased in vitro replication fitness (Mlcochova et al., 2021). This results in the high observed infectivity of the Delta variant, with reported higher viral burden in infected individuals and resulting in a higher probability of person-to-person transmission (Li et al., 2021; Scientific Pandemic Influenza Group on Modeling Operational subgroup, 2021; Teyssou et al., 2021). Indeed, the Delta reproductive number (R0) was calculated to range between 3.2 and 8 , which is up to three times more contagious than the original SARS-CoV-2 strain $(\mathrm{R} 0=2.79)$ (Liu and Rocklov, 2021)

Other SARS-CoV-2 variants are currently being monitored. The Epsilon variant, first recorded in South California with the S protein mutation L452R, accounted for a significant fraction of samples collected in the region at the beginning of 2021, in a retrospective study (Zhang et al., 2021a), and is now virtually disappearing. The C.37 variant, also known as Lambda, was first detected in Peru in December 2020 , bearing the same L452R mutation and, on the contrary, spread to many countries (Wink et al., 2021). One of the more recently emerging variants of COVID-19, Mu (also known as B.1.621), first detected in January 2021, quickly became the dominant strain in Colombia and spread to South America and Europe. The $\mathrm{Mu}$ variant contains several amino acid substitutions including E484K, N501Y, and P681H, which could confer a synergistic effect on vaccine resistance, transmissibility, and disease severity (Laiton-Donato et al., 2021). Even though these variants did not spread as largely as the VOCs, they are 
A

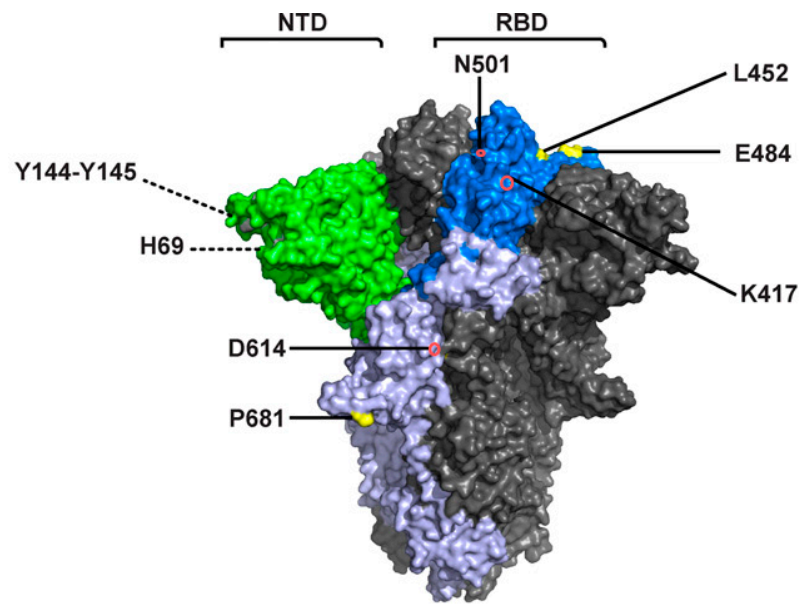

B

\begin{tabular}{|c|c|c|c|c|c|c|}
\hline \multirow{2}{*}{ Mutation } & \multicolumn{5}{|c|}{ Variant } & \multirow{2}{*}{ Significant biological effect } \\
\hline & B.1 & $\begin{array}{l}\text { B.1.1.7 } \\
\text { (Alpha) }\end{array}$ & $\begin{array}{c}\text { B.1.351 } \\
\text { (Beta) }\end{array}$ & $\begin{array}{c}\text { P.1 } \\
\text { (Gamma) }\end{array}$ & $\begin{array}{l}\text { B.1.617 } \\
\text { (Delta) }\end{array}$ & \\
\hline L18F & & & $\checkmark$ & $\checkmark$ & & \\
\hline $\mathrm{T} 20 \mathrm{~N}$ & & & & $\checkmark$ & & \\
\hline P26S & & & & $\checkmark$ & & \\
\hline$\Delta \mathrm{H} 69-70$ & & $\checkmark$ & & & & increased ACE2 binding (Starr et al. 2020) \\
\hline D80A & & & $\checkmark$ & & & \\
\hline $\mathrm{D} 138 \mathrm{Y}$ & & & & $\checkmark$ & & \\
\hline$\Delta \mathrm{Y} 144 / 145$ & & $\checkmark$ & & & & evasion of N5-loop antibodies (Wibmer et al. 2021) \\
\hline R190S & & & & $\checkmark$ & & \\
\hline D215G & & & $\checkmark$ & & & \\
\hline$\Delta \mathrm{L} 242-\mathrm{H} 245$ & & & $\checkmark$ & & & \\
\hline $\mathrm{R} 246 \mathrm{I}$ & & & $\checkmark$ & & & \\
\hline $\mathrm{K} 417 \mathrm{~N} / \mathrm{T}$ & & & $\vee(N)$ & $\vee(T)$ & & $\begin{array}{l}\text { evasion of class } 1 \text { antibodies (Wibmer et al. 2021), } \\
\text { vaccine-induced antibodies (Chen et al. 2021b; Liu et al. } \\
\text { 2021; Wu et al. 2021; Xie et al. 2021) }\end{array}$ \\
\hline L452R & & & & & $\checkmark$ & antibody evasion (Abdool Karim and de Oliveira 2021) \\
\hline $\mathrm{E} 484 \mathrm{~K} / \mathrm{Q}$ & & & $\vee(\mathrm{K})$ & $\checkmark(\mathrm{K})$ & $\vee(Q)$ & $\begin{array}{l}\text { evasion of class } 2 \text { antibodies (Li et al. 2020a; Cele et al. } \\
\text { 2021; Wang et al. 2021a; Wibmer et al. 2021), } \\
\text { vaccine-induced antibodies (Chen et al. 2021b; Liu et al. } \\
\text { 2021; Wu et al. 2021; Xie et al. 2021) }\end{array}$ \\
\hline N501Y & & $\checkmark$ & $\checkmark$ & $\checkmark$ & & $\begin{array}{l}\text { increased ACE2 binding (Starr et al. 2020), evasion of } \\
\text { infection- or vaccine-induced antibodies (Chen et al. 2021b; } \\
\text { Liu et al. 2021; Wu et al. 2021; Xie et al. 2021) }\end{array}$ \\
\hline A570D & & $\checkmark$ & & & & \\
\hline D614G & $\checkmark$ & $\checkmark$ & $\checkmark$ & $\checkmark$ & $\checkmark$ & $\begin{array}{l}\text { increased ACE2 binding (Korber et al. 2020; Yurkovetskiy } \\
\text { et al. 2020; Ozono et al. 2021), susceptibility to } \\
\text { neutralization (Weissman et al. 2021) }\end{array}$ \\
\hline $\mathrm{H} 655 \mathrm{Y}$ & & & & $\checkmark$ & & \\
\hline $\mathrm{P} 681 \mathrm{H} / \mathrm{R}$ & & $\vee(H)$ & & & $\vee(R)$ & increased spike-mediated cell fusion (Mlchocova et al. 2021) \\
\hline T716I & & $\checkmark$ & & & & \\
\hline A701V & & & $\checkmark$ & & & \\
\hline S982A & & $\checkmark$ & & & & \\
\hline T1027I & & & & $\checkmark$ & & \\
\hline $\mathrm{D} 1118 \mathrm{H}$ & & $\checkmark$ & & & & \\
\hline
\end{tabular}

Fig. 6. SARS-CoV-2 spike mutations in notable viral variants. (A) SARS-CoV-2 spike trimer and biologically relevant mutations, modeled on PDB 7C2L. One protomer is highlighted, showing the NTD in green and RBD in two shades of blue. Residues with dotted lines are hidden in this view. (B) Summary of SARS-CoV-2 variant-defining mutations and major biologic effects.

currently being monitored for their potential immune-evasive and infection-enhancing mutations.

After the identification of these variants, a main objective became the assessment of their ability to evade protective immune response. The expression of
S protein mutations found in Alpha on viral vectors (pseudoviruses) resulted in decreased monoclonal antibody neutralization; however, only minor potency loss was observed for polyclonal sera (Rees-Spear et al., 2021). On the contrary, in vitro assays with 
pseudoviruses expressing the spike of the Beta variant, which contains substitutions in the two immunodominant domains RBD and NTD, revelated that the neutralizing capacity of antibodies from convalescent patients was diminished against this variant (Wibmer et al., 2021). Substitution K417N induced reduced binding and neutralization from representative class 1 mAbs (that bind RBD in "up" position) from South African donors due to loss of a key hydrogen bond. Similarly, representative class 2 antibodies failed to bind Beta RBD, due to a missing contact point. Moreover, deletions in the NTD domain abrogated binding of N5-loop-directed antibodies. These studies provided evidence that the Beta variant can evade antibodies targeting highly immunogenic antigenic sites in the spike protein. Tested against sera from convalescent patients, Beta variant mutations induced a $10-$ to $15-$ fold reduction in mean neutralization titer (Cele et al., 2021; Wibmer et al., 2021). On the contrary, the Alpha variant was relatively more resistant to NTDdirected than RBD-directed mAbs and showed only partial reduced neutralization by convalescent serum (one out of 20 patients) (Wang et al., 2021a). This relative resistance can thus be associated largely to the E484K mutation, shared by Beta and Gamma variants. In areas where these viruses were common, there was concern of reinfection due to a second wave of variant strains infecting a population seropositive for the wild-type virus, as reported in Manaus, Brazil, which could pose a significant safety risk (Sabino et al., 2021). Importantly, the appearance of a E484K mutation was reported in a small fraction of Alpha viruses (11 out of 214159 sequences), suggesting that the United Kingdom variant could potentially acquire this change (Public Health England, 2021). More recently, the Delta variant was shown to be 4- to 6fold less sensitive than other variants to serum neutralizing antibodies from recovered individuals (Mlcochova et al., 2021; Planas et al., 2021). In vitro, viruses with Delta spike exhibited higher resistance to neutralization with mAbs, denoting that the rapid spread of Delta was associated with the potential to escape antibody-mediated protection (Mlcochova et al., 2021; Planas et al., 2021).

The immune escape of E484K-bearing viruses was observed also for mAbs used in the clinic. LY-CoV555 alone and in combination with CB6 was inactive against Beta and, similarly, the activity of REGN10933 alone was impaired (Wang et al., 2021a). Due to resistance of viral variants, in April 2021, FDA revoked its previously issued EUA for bamlanivimab alone, which remained approved as part of a combination therapy with etesevimab (Food and Drug Administration, 2021a). Decreased binding to spike proteins containing E484K, D614G, and N501Y mutations was also observed for other mAbs (Chen et al., 2021b).
Additionally, S protein mutations N234Q, L452R (detected in Epsilon and Delta variants), A475V, and $\mathrm{V} 483 \mathrm{~A}$ were found to induce escape from mAbs ( $\mathrm{Li}$ et al., 2020a). The reasons behind the origin of these antibody escape mutants could be twofold: the high level of SARS-CoV-2 transmission rates, likely resulting in higher chances of emergence of mutated viruses, and the large proportion of commonly shared public antibodies expressing VH3-53/66 and VH1-24 that induced selective pressure on key $\mathrm{S}$ protein RBD and NTD residues (Wibmer et al., 2021). Importantly, many mAbs under clinical development derived from the same public antibodies, raising concerns on the future efficacy of these treatments (Marovich et al., 2020).

\section{B. Implications for Vaccines}

The emergence of SARS-CoV-2 variants had important implications for vaccine development. The impact of SARS-CoV-2 variants was observed on the clinical trials conducted in countries where the variants emerged during the course of the study and prompted the vaccine developers to initiate extensive studies to understand the effect on vaccination campaigns (Abdool Karim and de Oliveira, 2021).

The first mutation to be recorded, D614G, was suggested not to be an obstacle to vaccine development due to enhanced vulnerability to neutralization (Weissman et al., 2021). On the contrary, neutralizing antibody activity of the two mRNA vaccines was reported to be lower against the Beta variant's mutations. Using pseudovirus neutralization assays, reduction of neutralization by a factor of 6.4 was detected in serum obtained from mRNA-1273 vaccinees, whereas neutralization was reduced 0.8- to 9-fold in serum from BNT162b2 vaccinees (Chen et al., 2021b; Liu et al., 2021; Wu et al., 2021; Xie et al., 2021). Reduced binding to Betaassociated mutations was also determined for eight out of $12(67 \%)$ serum samples from recipients of the GamCOVID-Vac vaccine (Ikegame et al., 2021). Evidence from in vitro analyses resulted in only a minor effect of the Alpha mutations, highlighting again the escape effect of the K417N, E484K, and N501Y substitutions (Garcia-Beltran et al., 2021).

A decrease in efficacy was observed for viral vectored, recombinant protein, and mRNA vaccines tested during the insurgence of the SARS-CoV-2 variants. The vaccine efficacy of ChAdOx1 was $75 \%$ when determined before the emergence of SARS-CoV2 variants. A preliminary analysis reported that the vaccine provided a similar, yet reduced, level of neutralization against the Alpha variant mutations expressed on pseudoviruses. The mean fold change of the Alpha variant versus wild-type was 3.2 and 1.9 for the first and second dose vaccine sera (Collier et al., 2021). However, in a phase $1 / 2$ study in South Africa, protection against mild-to-moderate COVID- 
19 was $21.9 \%$ in the overall study population, and it was calculated to be only $10.4 \%$ against the Beta variant. Impact of this variant on hospitalization rate was not observed, likely due to the exclusion of 65 and older people from the trial (Madhi et al., 2021).

In a phase $2 \mathrm{~b}$ trial conducted in South Africa, where approximately $90 \%$ of the cases were attributed to the Beta variant, a vaccine efficacy of $49.4 \%$ was reported for NVX-CoV2373 against PCR-confirmed, symptomatic COVID-19, or 60\% if HIV-positive individuals in the trial population were removed from the analysis. On the contrary, interim analysis of a phase 3 trial in the United Kingdom, in which Alpha was detected in over half of the PCR-confirmed symptomatic cases, resulted in overall $89.3 \%$ estimated vaccine efficacy. Efficacy by strain was calculated to be $95.6 \%$ against the original SARS-CoV-2 strain and $85.6 \%$ against the United Kingdom variant (Callaway and Mallapaty, 2021; Novavax, 2021). Efficacy for a second recombinant protein vaccine, SCB2019 , was reported to be $79 \%$ in a context where $100 \%$ of SARS-CoV-2 strains were variants, with Delta as the predominant strain. Interestingly, in this randomized trial, SCB-2019 also showed a 64\% reduced risk of reinfection in previously infected individuals (Clover, 2021).

For Ad26.COV2.S, a phase 3 study conducted in areas of high COVID-19 incidence and where variants were emerging demonstrated a global efficacy of $66.1 \%$ (at $\geq 28$ days postadministration) against PCRconfirmed moderate to severe disease. In the United States, where the D614G strain is dominant, efficacy was $72 \%$, whereas in Brazil, with a high prevalence of Zeta variant, efficacy was $68.1 \%$. In South Africa, where almost all cases were caused by Beta, efficacy was $52.0 \%$ (Sadoff et al., 2021a).

For $\mathrm{CVnCoV}$, a vaccine efficacy of $47 \%$ was reported against PCR-confirmed COVID-19 disease of any severity, in the context of high prevalence of SARS-CoV-2 variants (CureVac, 2021). In similar settings, other mRNA vaccines showed reduced effectiveness although maintaining a high degree of protection against COVID-19. For instance, in Qatar, an effectiveness of $87.0 \%$ and $100 \%$ was estimated against the Alpha variant and $72.1 \%$ and $96.4 \%$ against the Beta variant for BNT162b2 and mRNA-1273 (Abu-Raddad et al., 2021; Chemaitelly et al., 2021b). This apparent difference in vaccine performance could be due to the insufficient immunogenicity resulting from the use of unmodified mRNA bases [CVnCoV does not use uracil-modified mRNA, which is deemed to be critical in inducing high protein expression (Karikó et al., 2005)] or from the low dose used (12 $\mu \mathrm{g}$ compared with $100 \mu \mathrm{g}$ for mRNA1273 and $30 \mu \mathrm{g}$ for BNT162b2). A next-generation vaccine with optimized noncoding regions, $\mathrm{CV} 2 \mathrm{CoV}$, also using nonmodified RNA bases, is currently being developed in collaboration with GSK. In NHPs, $\mathrm{CV} 2 \mathrm{CoV}$ induced substantially higher immune responses compared with the first-generation $\mathrm{CVnCoV}$, including more potent neutralization against SARSCoV-2 variants (Gebre et al., 2021).

Reduction of vaccine effectiveness in a real-world setting was also reported after the rapid global spread of the Delta variant. In vitro, Delta was reported to be eight-fold less sensitive to vaccine-elicited antibodies as compared with the Wuhan D614G strain after two doses of ChAdOx1 or BNT162b2 vaccines (Mlcochova et al., 2021). Vaccine effectiveness against Delta was lower when compared with that against Alpha: $88 \%$ versus $93.7 \%$ and $67 \%$ versus $74.5 \%$, after two doses of BNT162b2 and ChAdOx1, respectively, as reported in a test-negative case-control study in the UK (Lopez Bernal et al., 2021). In studies from Israel, Qatar, and the UK, BNT162b2 vaccine efficacy was observed to decrease with time, suggesting an increased risk of Delta variant infection months after vaccination (Chemaitelly et al., 2021a; Goldberg et al., 2021; Pouwels et al., 2021).

\section{Discussion}

\section{A. Considerations on Immune Response to Natural Infection and Vaccination}

The induction of neutralizing antibodies is a key objective of vaccination strategies against viral targets. A detailed understanding of the human antibody response to SARS-CoV-2 is therefore critical to develop effective COVID-19 vaccines (Burton and Walker, 2020). Potent neutralizing antibodies have been identified by several research groups, most of which target the RBD domain of S protein and interfere with ACE2 receptor binding. In contrast to many other viral infections for which the accumulation of somatic hypermutation and clonal B cell selection is often observed in time, SARS-CoV-2 neutralizing antibodies isolated from convalescent patients showed limited accumulation of mutations (Kreer et al., 2020). This is likely due to a rapid viral clearance and the limited amount of available antigen, or the limited access to the germinal center (Kreer et al., 2020). Another explanation could be prior exposure to other human coronaviruses (Rydyznski Moderbacher et al., 2020). Importantly, the antibody response to RBD appears to be dominated by near-germline sequences coded by the VH3-53 gene, binding conserved residues such as K417 and E484 (Wu et al., 2020a; Yuan et al., 2020), which represent a pool of shared antibody responses among individuals. Despite their limited affinity maturation requirement to achieve a potent neutralization, these sequences could be ideal for vaccine design; unfortunately, the residues targeted by these public antibodies are the ones mutated in emerging escape viral variants, which significantly 
reduced the neutralization potency of sera from both convalescent and vaccinated individuals (Andreano and Rappuoli, 2021). With these considerations in mind, the use of immunogens that elicit other germline sequences less affected by viral escape could be a valuable strategy. In line with this, the selection of mAbs targeting highly conserved spike regions and the update of existing mAb cocktails could be envisioned to chase and stop escape mutants.

After the induction of a protective immune response, durability of immunity is a critical parameter to consider either after infection or vaccination. Immunity to SARS-CoV-2 infection was studied up to one year after infection. Antibodies against $S$ protein and RBD declined moderately over time. Memory B cells increased between 1 and 8 months after infection, whereas memory $\mathrm{CD} 4+$ and $\mathrm{CD} 8+\mathrm{T}$ cells declined with an initial half-life of 3-5 months (Dan et al., 2021). In another study, memory $B$ cell levels were consistent with antigen persistence, suggesting robust activation of germinal centers, with a dominance of antibodies encoded by the VH3-53 gene (Gaebler et al., 2021). In case of active immunization, neutralizing antibodies have been reported to persist up to 6 months after a second dose of mRNA-1273 (Doria-Rose et al., 2021) and BNT162b2 (with a more rapid decline in the first 3 months from vaccination) (Levin et al., 2021; Naaber et al., 2021). Robust memory B cell responses were shown to last at least 6 months after mRNA vaccination (Goel et al., 2021b; Wang et al., 2021c). Strong recall memory was also demonstrated after one mRNA vaccine dose in individuals previously exposed to the virus (Goel et al., 2021a). These observations are crucial for recall responses after natural infection and vaccination. Indeed, vaccination of previously infected individuals has been shown to generate a strong humoral and cellular recall response, with evidence of extremely high neutralizing antibodies titers (Fig. 2B). Several research groups have reported that a single mRNA vaccine dose boosted infectionacquired immunity, with neutralizing antibodies up to a thousand times higher than the ones in virus-naïve individuals (Krammer et al., 2021; Prendecki et al., 2021; Stamatatos et al., 2021). Moreover, antibody titers were substantially boosted and compared with previous infection or vaccination alone (Reynolds et al., 2021). This boosting effect also involved cellular immune responses, with recall of S1 and S2 specific $\mathrm{T}$ cells (Prendecki et al., 2021). Importantly, the recall antibody response induced by mRNA vaccination in individuals that experienced SARS-CoV-2 infection was demonstrated to be crossneutralizing with the Beta variant, even at lower titers (Stamatatos et al., 2021). Interestingly, crossneutralizing antibody responses were due to anti-RBD antibodies whereas the NTD domain, which carries mutations/ deletions in SARS-CoV-2 variants, did not appear to be a target of crossneutralizing antibodies. In another study, mRNA vaccination after SARS-CoV-2 infection increased the number of RBD-binding memory cells by more than an order of magnitude and recruited new $B$ cell clones, expanding breadth of response (Wang et al., 2021b). Boosting of immune response with single-dose immunization and elicitation of crossprotective immunity has important implications for vaccines. This phenomenon, termed "hybrid immunity," is proposed to derive from vaccine-induced activation of abundant memory $\mathrm{B}$ and $\mathrm{T}$ cells previously generated during natural infection (Crotty, 2021). Looking ahead, a combination of vaccine modalities and design of booster immunizations could be envisioned to achieve this effect also in virus-naïve individuals.

\section{B. Considerations for Vaccines}

Efforts to rapidly develop a first wave of COVID-19 vaccines focused on the elicitation of antibody responses to the spike protein, achieving high efficacy against the original SARS-CoV-2 virus (Hacisuleyman et al., 2021). However, mutations caused by either natural evolution or selective pressure by the immune system impacted the effectiveness of some vaccines (Karim, 2021).

The appearance of novel SARS-CoV-2 variants greatly complicated the measurement of vaccine efficacy in clinical trial, which saw rapidly changing scenarios when a new immune-resistant strain suddenly emerged. Despite good results in the United Kingdom, where ChAdOx1 exhibited a vaccine efficacy of $70 \%$, the vaccine's distribution was halted in South Africa due to a low efficacy of $22 \%$ as a result of a high prevalence of the Beta variant (Madhi et al., 2021). This opened question on the targets of the vaccine-elicited immunity. The extreme drop in neutralization titer against Beta, bearing three distinct mutations in the RBD region, suggested that much, though not all, of the ChAdOx1 vaccine-elicited neutralization was directed against the RBD (Madhi et al., 2021). Similarly, the neutralizing activity of the two mRNA vaccines against the Beta variant was reported to be 0.8-9 times lower, whereas a minor difference was evident against the Alpha variant. Other vaccines, NVX-CoV2373 and Ad26.COV2.S, registered decreased efficacy when tested in countries where Beta is present. Initial breakthrough cases of vaccineelicited immunity were reported in the case of mRNA vaccination, when two fully vaccinated individuals developed COVID-19 caused by variant virus (Hacisuleyman et al., 2021). These findings underlined the importance of eliciting a diverse crossprotective antibody immunity via vaccination, which is critical to decrease the probability of viral escape from common antibody lineages elicited by first-generation vaccines. $\mathrm{Wu}$ and colleagues reported that 6 months after 
mRNA vaccination, all individuals retained potent serum neutralizing titer against wild-type SARS-CoV2 , but only $50 \%$ of them had measurable neutralizing titers against Beta and Gamma variants (Wu et al., 2021). Importantly, waning immunity was observed, with a significant decline in spike-specific antibody levels as early as 2 months after full vaccination (Shrotri et al., 2021). Vaccine efficacy estimated over 2-month periods was also reported to decline in time, from 96.2\% (starting with 7 days after two BNT162b2 doses) to $83.7 \%$ (starting with 4 months postvaccination) (Thomas et al., 2021). A recent modeling study in Israel showed a significantly higher risk for infection for early vaccinees compared with those vaccinated later (Mizrahi et al., 2021). With the spread of Delta variant, which rapidly became the dominant SARSCoV-2 strain, more breakthrough infections were reported even in countries with high vaccine coverage (Bergwerk et al., 2021). These events prompted the deployment of two strategies to enhance effectiveness against viral variants and boost immunity of the first wave of COVID-19 vaccines. The first one, homologous booster vaccination, was used to potentiate the twodose mRNA vaccination schedule and counteract waning immunity. Higher neutralizing titers is thought to be sufficient to stop emerging variants such as Delta, against which serum neutralization capacity is decreased. After rapid implementation of booster vaccination in the population, a recent study from Israel showed that a booster dose administered to individuals aged $\geq 60$ years at $>5$ months after the two-dose series lowered the rates of confirmed infection and severe illness by a factor of 11.3 and 19.5, respectively, compared with those not receiving a booster (Bar-On et al., 2021). Deployment of booster doses in at-risk people at least 6 months after full vaccination was indeed rapidly authorized by the FDA (Food and Drug Administration, 2021c). However, an important consideration is that boosting vaccinated individuals with currently available mRNA vaccines might produce strong responses that mirror their initial vaccine responses to wild-type virus but with potentially low coverage against variants, as observed by Cho and colleagues (Cho et al., 2021). The second strategy, heterologous vaccination, aims at developing a broader immune response, similarly to the hybrid immunity observed for vaccination of previously infected individuals. A booster dose with a modified mRNA vaccine designed to target the Beta variant is being developed and induced a broader crossreactive response (Choi et al., 2021). This evidence supports the development of second-generation vaccines tailored against emerging and future variants, exploiting the rapid development pace of mRNA vaccines. Alternatively, heterologous primeboost with adeno-vectored and mRNA vaccine elicited
4.5 and 2.6 times higher neutralizing titers against Alpha and 8.6 and 5.8 times higher neutralizing titers against Beta compared with homologous prime-boost with ChAdOx1 and BNT162b2, respectively (Hillus et al., 2021). This approach could be used to enhance protection of individuals previously immunized with vaccines that are more likely to be escaped by emerging variants. Despite the two booster strategies described, it remains clear that determining the real efficacy of vaccines against viral variants, and particularly translating immunity to efficacy against disease, is challenging; thus, the identification of correlates of protection is still paramount to guide coordinated vaccination efforts.

\section{Correlates of Protection}

Correlates of protection have yet to been defined for COVID-19 vaccines, but they are critically important to rapidly evaluate vaccine efficacy and to enable timely reactions to the emergence of concerning variants (Karim, 2021). Accumulating data from animal models and clinical trials on the relationship between antibody levels and efficacy suggest that antibodies play a major role in protecting from SARS-CoV-2 infection. Indeed, passive transfer of neutralizing antibodies was reported to prevent SARS-CoV-2 infection in NHPs (McMahan et al., 2021). In addition, studies in NHPs also pointed toward the role of antibody-dependent effector functions, particularly when CD8 + T cells are elicited (McMahan et al., 2021).

Due to the rapid evolution of SARS-CoV-2, vaccine efficacy has become increasingly difficult to demonstrate in clinical trial settings, as data are only generated for the variants dominant at a particular time and place. Emergence of SARS-CoV-2 variants also affects realworld vaccine effectiveness (likely to vary with everchanging distribution of variants) and vaccine-induced protection, which will also decrease due to waning immunity. Determining correlates of protection in humans is complicated due to the absence of standardized clinical trial endpoints and assays for evaluation of immune response (World Health Organization, 2021a). Nonetheless, using current data from vaccines trials and convalescents, two independent studies found a strong correlation between neutralizing antibodies levels and protection from SARS-CoV-2 infection. Earle et al. determined correlation between postimmunization neutralizing titer and vaccine efficacy (Earle et al., 2021). Moreover, Khoury and colleagues estimated that a neutralizing titer approximately $20 \%$ of the average convalescent level was necessary to achieve $50 \%$ protection from disease, and that an even lower level (3\%) was sufficient to protect from severe infection (Khoury et al., 2021). The role of vaccine-induced cellular mediated immunity is still under investigation. SARS-CoV-2 spike mRNA vaccines mediate protection from severe 
disease early after the first dose, when antibody titer is low. In this early window, functional vaccine-induced CD8+ T cells could be responsible for part of the protective efficacy of mRNA vaccines (Oberhardt et al., 2021). Structure-based network analysis was used to define mutationally constrained CD8 $+\mathrm{T}$ cell epitopes across the SARS-CoV-2 proteome, a finding that could be used to design novel T-cell-based vaccines against emerging variants and other coronaviruses (Nathan et al., 2021).

\section{Perspective: The Challenges Ahead}

The first generation of COVID-19 vaccines demonstrated efficacy significantly above the $50 \%$ lower limit recommended by the WHO and considered by FDA for licensure, with all candidates protecting from COVID-19 disease and up to $95 \%$ vaccine efficacy estimates. A vaccine that has at least $50 \%$ efficacy may in theory provide protection in vaccinated individuals (Krause et al., 2020). However, the appearance of SARS-CoV-2 variants dramatically reduced the effectiveness of some vaccines and shifted the requirements for herd immunity, prompting new research strategies against emerging viral mutants. Aside from boosting existing vaccine-induced immunity, a second generation of COVID-19 vaccines could be deployed to achieve enhanced protection against identified variants and potentially new ones (Choi et al., 2021). For this reason, active research for a "pan-corona" vaccine is pushing the field toward new solutions (Cohen, 2021a). Broad protection and crossreactive immunity will likely have to be assessed in case of vaccination of previously infected or previously vaccinated people. A critical aspect would be a better understanding of the plasticity of the immune response in these individuals. Although homologous boosting increases both neutralizing antibody titers and cellular immunity, studies will have to be focused on determining how a primed immune system can be effectively reprogrammed toward new specificities, or whether preexisting immunity will dominate recall responses. The phenomenon of continuous recall of $B$ cells activated by past immunizations was observed for influenza vaccines ("original antigenic sin") and will be an important consideration for future vaccination strategies against SARS-CoV-2. For this reason, studying the evolution of the human $\mathrm{B}$ cell repertoire after immunization is critical to elucidate the underlying parameters that contribute to the broadening of immune responses. Optimal localization of the immune response is also an important parameter to consider. An increased understanding of how to elicit robust mucosal immunity will provide a more robust first line of defense against the virus. To achieve this, intranasal vaccination could be used, a route of immunization being considered for ChAdOx1 and other vaccines (Lund and Randall, 2021).
A second consideration for a new generation of COVID-19 vaccines is the assessment of evolution of viral epidemiology and its impact on human health. A better understanding of viral mutation, escape, and distribution in the biosphere will inform scientists on the most appropriate vaccination strategies. Continuous mapping of viral mutations and data integration with laboratory experiments will be needed. In this regard, the isolation of mAbs will allow precise mapping of escaping epitopes, thus allowing rational design of optimized antigens (Correia et al., 2014). Together, accumulation of structural and epidemiology data will provide an unparalleled understanding of viral protein evolution. The 5-year strategic plan recently launched by the Coalition for Epidemic Preparedness Innovations might address most of these issues, including surveillance of new emerging SARSCoV-2 variants and development of broadly protective vaccines, with a proposal to compress vaccine development timelines from 1 year to 100 days (Samarasekera, 2021). Similar strategic plans are also considered by the United States and European Union governments, aimed at funding multibillion dollar end-to-end solution from surveillance to rapid development and manufacture of vaccines, treatments, and diagnostics.

A third consideration for future SARS-CoV-2 vaccines is safety and reactogenicity. Although current vaccines have an acceptable reactogenicity profile, the frequency of adverse events may vary between age groups, and safety concerns were raised for both adenovirus and RNA vaccines (Angeli et al., 2021). A better safety profile will be necessary for a second generation of vaccines. Particularly, continuous monitoring of anaphylaxis and other adverse events in the population is needed, together with assessment of long-term safety and efficacy. Refined and improved formulations will likely allow a better safety profile and even an improved storage and handling of vaccines.

This leads us to the last point to consider, which is not the least in terms of importance. Most of the industrialized world is quickly rolling out vaccines, with access being broadened to all age groups. However, developing countries are lagging, with difficult access to costly, degradable, highly efficacious vaccines. The WHO estimated that if all available doses were distributed equitably, all health workers and older people worldwide would have been already vaccinated. Despite the availability of a sufficient number of doses globally, lack of access to vaccines in low- and lower-middle-income countries means that WHO's target of stopping the pandemic by vaccinating $\geq 40 \%$ of people in every country by the end of 2021 and $\geq 70 \%$ by the first half of 2022 will not be reached (World Health Organization, 2021e). 
Equitable access to vaccination needs to be placed at the center of all current and future vaccination strategies, and worldwide roll-out capability will have to be an important comparator of next-generation vaccines. Fast and equitable supply requires discussion in the regulatory domain supporting implementation of common principles and initiatives for equitable access (Azevedo Soares, 2020). From the manufacturing perspective, it will be important to scale up operations and to define quality specifications, together with a strong stability strategy and comparability of analytical assays and product validation from multiple manufacturing sites (World Health Organization, 2021d).

In conclusion, in less than 2 years we have experienced a massive effort to map regions of vulnerability of SARS-CoV-2 virus and to understand how the immune system reacts to it. The accumulation of knowledge was used to parallel-develop highly effective vaccines in record time, making them available to the general population, yet disparities in vaccine access emerged. At the same time, viral evolution into variants that escape common antibody responses elicited by the original strain prompted a new wave of development effort, which will likely result in even more effective and safe second-generation vaccines. Learnings from the COVID-19 pandemic is ultimately changing the way we approach vaccinology and will hopefully result in a better understanding of our immunity and in a technological leap that could be used to design effective treatments for other infectious and noninfectious diseases.

\section{Methods}

This review is based on SARS-CoV-2 and COVID-19 related data published in English encompassing the time period between late 2019, when the virus was first reported, up to September 2021. Studies related to SARS-CoV-2 immunology and vaccines from PubMed, Biorxiv, and Medrxiv, as well as certain press releases were considered for inclusion. Studies of seasonal and epidemic coronaviruses, including SARS-CoV-1 and MERS-CoV, were considered for inclusion. Both animal and human studies related to SARS-CoV-2 were considered for inclusion.

\section{Authorship Contributions}

Wrote or contributed to the writing of the manuscript: Pecetta, Kratochvil, Kato, Vadivelu, Rappuoli.

\section{Acknowledgments}

The authors thank Dr. Roberta Cozzi for rendering the SARSCoV-2 S protein in Fig. 2. The authors also thank Modis for editorial assistance and manuscript coordination, on behalf of GSK. Petronela M. Petrar provided editorial support, and Sander Hulsmans and Stephanie Deroo coordinated the manuscript development.

\section{References}

Abbas AK, Lichtman AH, and Pillai S (2012) Cellular and Molecular Immunology, Elsevier Saunders, Philadelphia.

Abdool Karim SS and de Oliveira T (2021) New SARS-CoV-2 variants-clinical, public health, and vaccine implications. $N$ Engl J Med 384:1866-1868.

Abu-Raddad LJ, Chemaitelly H, and Butt AA; National Study Group for COVID-19 Vaccination (2021) Effectiveness of the BNT162b2 Covid-19 vaccine against the B.1.1.7 and B.1.351 variants. N Engl J Med 385:187-189.

Adams ER, Ainsworth M, Anand R, Andersson MI, Auckland K, Baillie JK, Barnes E, Beer S, Bell JI, Berry T, et al.; National COVID Testing Scientific Advisory Panel (2020) Antibody testing for COVID-19: a report from the National COVID Scientific Advisory Panel. Wellcome Open Res 5:139.

Andersen KG, Rambaut A, Lipkin WI, Holmes EC, and Garry RF (2020) The proximal origin of SARS-CoV-2. Nat Med 26:450-452.

Anderson EJ, Rouphael NG, Widge AT, Jackson LA, Roberts PC, Makhene M, Chappell JD, Denison MR, Stevens LJ, Pruijssers AJ, et al.; mRNA-1273 Study Group (2020) Safety and immunogenicity of SARS-CoV-2 mRNA-1273 vaccine in older adults. N Engl J Med 383:2427-2438.

Andreano E, Nicastri E, Paciello I, Pileri P, Manganaro N, Piccini G, Manenti A, Pantano E, Kabanova A, Troisi M, et al. (2021) Extremely potent human monoclonal antibodies from COVID-19 convalescent patients. Cell 184: 1821-1835.e16.

Andreano E and Rappuoli R (2021) Immunodominant antibody germlines in COVID-19. J Exp Med 218:e20210281.

Angeli F, Spanevello A, Reboldi G, Visca D, and Verdecchia P (2021) SARS-CoV-2 vaccines: lights and shadows. Eur J Intern Med 88:1-8.

Anguela XM and High KA (2019) Entering the modern era of gene therapy. Annu Rev Med 70:273-288.

Arvin AM, Fink K, Schmid MA, Cathcart A, Spreafico R, Havenar-Daughton C, Lanzavecchia A, Corti D, and Virgin HW (2020) A perspective on potential antibody-dependent enhancement of SARS-CoV-2. Nature 584:353-363.

AstraZeneca (Press release, March 25, 2021) AZD1222 US phase III primary analysis confirms safety and efficacy. (http://www.astrazeneca.com/content/astraz/media-centre/ press-releases/2021/azd1222-us-phase-iii-primary-analysis-confirms-safety-and-efficacy. html; accessed: September 24, 2021.)

Azevedo Soares A (2020) Ensuring equitable access to COVID-19 vaccines. Bull World Health Organ 98:826-827.

Baden LR, El Sahly HM, Essink B, Kotloff K, Frey S, Novak R, Diemert D, Spector SA, Rouphael N, Creech CB, et al.; COVE Study Group (2021) Efficacy and safety of the mRNA-1273 SARS-CoV-2 vaccine. N Engl J Med 384:403-416.

Barda N, Dagan N, Ben-Shlomo Y, Kepten E, Waxman J, Ohana R, Hernán MA, Lipsitch M, Kohane I, Netzer D, et al. (2021) Safety of the BNT162b2 mRNA Covid-19 vaccine in a nationwide setting. N Engl J Med 385:1078-1090.

Bar-On YM, Goldberg Y, Mandel M, Bodenheimer O, Freedman L, Kalkstein N, Mizrahi B, Alroy-Preis S, Ash N, Milo R, et al. (2021) Protection of BNT162b2 vaccine booster against Covid-19 in Israel. N Engl J Med 385:1393-1400.

Barnes CO, Jette CA, Abernathy ME, Dam KA, Esswein SR, Gristick HB, Malyutin AG, Sharaf NG, Huey-Tubman KE, Lee YE, et al. (2020a) SARS-CoV-2 neutralizing antibody structures inform therapeutic strategies. Nature 588:682-687.

Barnes CO, West Jr AP, Huey-Tubman KE, Hoffmann MAG, Sharaf NG, Hoffman PR, Koranda N, Gristick HB, Gaebler C, Muecksch F, et al. (2020b) Structures of human antibodies bound to SARS-CoV-2 spike reveal common epitopes and recurrent features of antibodies. Cell 182:828-842.e16.

Barrett JR, Belij-Rammerstorfer S, Dold C, Ewer KJ, Folegatti PM, Gilbride C, Halkerston R, Hill J, Jenkin D, Stockdale L, et al.; Oxford COVID Vaccine Trial Group (2021) Phase $1 / 2$ trial of SARS-CoV-2 vaccine ChAdOx $1 \mathrm{nCoV}-19$ with a booster dose induces multifunctional antibody responses. Nat Med 27:279-288.

Bartsch YC, Fischinger S, Siddiqui SM, Chen Z, Yu J, Gebre M, Atyeo C, Gorman MJ, Zhu AL, Kang J, et al. (2021) Discrete SARS-CoV-2 antibody titers track with functional humoral stability. Nat Commun 12:1018.

Batra M, Tian R, Zhang C, Clarence E, Sacher CS, Miranda JN, De La Fuente JRO, Mathew M, Green D, Patel S, et al. (2021) Role of IgG against N-protein of SARS-CoV2 in COVID-19 clinical outcomes. Sci Rep 11:3455.

Baum A, Ajithdoss D, Copin R, Zhou A, Lanza K, Negron N, Ni M, Wei Y, Mohammadi K, Musser B, et al. (2020a) REGN-COV2 antibodies prevent and treat SARS-CoV-2 infection in rhesus macaques and hamsters. Science 370:1110-1115.

Baum A, Fulton BO, Wloga E, Copin R, Pascal KE, Russo V, Giordano S, Lanza K, Negron N, Ni M, et al. (2020b) Antibody cocktail to SARS-CoV-2 spike protein prevents rapid mutational escape seen with individual antibodies. Science 369:1014-1018.

Bergwerk M, Gonen T, Lustig Y, Amit S, Lipsitch M, Cohen C, Mandelboim M, Levin EG, Rubin C, Indenbaum V, et al. (2021) Covid-19 breakthrough infections in vaccinated health care workers. $N$ Engl J Med 385:1474-1484.

Brodin P (2021) Immune determinants of COVID-19 disease presentation and severity. Nat Med 27:28-33.

Brouwer PJM, Antanasijevic A, Berndsen Z, Yasmeen A, Fiala B, Bijl TPL, Bontjer I, Bale JB, Sheffler W, Allen JD, et al. (2019) Enhancing and shaping the immunogenicity of native-like HIV-1 envelope trimers with a two-component protein nanoparticle. Nat Commun 10:4272.

Brouwer PJM, Caniels TG, van der Straten K, Snitselaar JL, Aldon Y, Bangaru S, Torres JL, Okba NMA, Claireaux M, Kerster G, et al. (2020) Potent neutralizing antibodies from COVID-19 patients define multiple targets of vulnerability. Science 369:643-650.

Burton DR and Walker LM (2020) Rational vaccine design in the time of COVID19. Cell Host Microbe 27:695-698.

Callaway E and Mallapaty S (2021) Novavax offers first evidence that COVID vaccines protect people against variants. Nature $\mathbf{5 9 0}: 17$ 
CanSino (Press release, February 24, 2021) NMPA accepts the application for conditional marketing authorization of CanSinoBIO's COVID-19 vaccine Convidecia (http://www.cansinotech.com/html/1///179/180/651.html; accessed: April 24, 2021).

Case JB, Rothlauf PW, Chen RE, Kafai NM, Fox JM, Smith BK, Shrihari S, McCune BT, Harvey IB, Keeler SP, et al. (2020) Replication-competent vesicular stomatitis virus vaccine vector protects against SARS-CoV-2-mediated pathogenesis in mice. Cell Host Microbe 28:465-474.e4.

Cele S, Gazy I, Jackson L, Hwa S-H, Tegally H, Lustig G, Giandhari J, Pillay S, Wilkinson E, Naidoo Y, et al.; Network for Genomic Surveillance in South Africa COMMIT-KZN Team (2021) Escape of SARS-CoV-2 501Y.V2 from neutralization by convalescent plasma. Nature 593:142-146.

Celltrion (Press release, March 26, 2021) EMA issues advice on the use of Celltrion's anti-COVID-19 monoclonal antibody treatment regdanvimab (CT-P59) for COVID19 patients in the European Union. (http://www.celltrionhealthcare.com/en-us/board newsdetail?modify_key=465\&pagenumber=1\&keyword=\&keyword_type=; accessed: September 24, 2021)

Chan JF, Kok KH, Zhu Z, Chu H, To KK, Yuan S, and Yuen KY (2020) Genomic characterization of the 2019 novel human-pathogenic coronavirus isolated from a patient with atypical pneumonia after visiting Wuhan. Emerg Microbes Infect 9:221-236

Chang CK, Sue SC, Yu TH, Hsieh CM, Tsai CK, Chiang YC, Lee SJ, Hsiao HH, Wu WJ, Chang WL, et al. (2006) Modular organization of SARS coronavirus nucleocapsid protein. J Biomed Sci 13:59-72.

Channappanavar R and Perlman S (2017) Pathogenic human coronavirus infections: causes and consequences of cytokine storm and immunopathology. Semin Immunopathol 39:529-539.

Chaudhary N, Weissman D, and Whitehead KA (2021) mRNA vaccines for infectious diseases: principles, delivery and clinical translation. Nat Rev Drus Discov 20:817-838 [Published correction appears in Nat Rev Drug Discov 20:880].

Chemaitelly H, Tang P, Hasan MR, AlMukdad S, Yassine HM, Benslimane FM, Al Khatib HA, Coyle P, Ayoub HH, Al Kanaani Z, et al. (2021a) Waning of BNT162b2 vaccine protection against SARS-CoV-2 infection in Qatar. $N$ Engl $J$ Med 385:e83.

Chemaitelly H, Yassine HM, Benslimane FM, Al Khatib HA, Tang P, Hasan MR, Malek JA, Coyle P, Ayoub HH, Al Kanaani Z, et al. (2021b) mRNA-1273 COVID19 vaccine effectiveness against the B.1.1.7 and B.1.351 variants and severe COVID-19 disease in Qatar. Nat Med 27:1614-1621.

Chen P, Nirula A, Heller B, Gottlieb RL, Boscia J, Morris J, Huhn G, Cardona J, Mocherla B, Stosor V, et al.; BLAZE-1 Investigators (2021a) SARS-CoV-2 neutralizing antibody LY-CoV555 in outpatients with Covid-19. $N$ Engl J Med 384:229-237.

Chen RE, Zhang X, Case JB, Winkler ES, Liu Y, VanBlargan LA, Liu J, Errico JM, Xie X, Suryadevara N, et al. (2021b) Resistance of SARS-CoV-2 variants to neutralization by monoclonal and serum-derived polyclonal antibodies. Nat Med 27:717-726.

Chen Y, Liu Q, and Guo D (2020) Emerging coronaviruses: genome structure, replication, and pathogenesis. J Med Virol 92:418-423.

Chi X, Yan R, Zhang J, Zhang G, Zhang Y, Hao M, Zhang Z, Fan P, Dong Y, Yang Y, et al. (2020) A neutralizing human antibody binds to the N-terminal domain of the spike protein of SARS-CoV-2. Science 369:650-655.

Cho A, Muecksch F, Schaefer-Babajew D, Wang Z, Finkin S, Gaebler C, Ramos V, Cipolla M, Mendoza P, Agudelo M, et al. (2021) Anti-SARS-CoV-2 receptorbinding domain antibody evolution after mRNA vaccination. Nature 600:517-522

Choi A, Koch M, Wu K, Chu L, Ma L, Hill A, Nunna N, Huang W, Oestreicher J, Colpitts T, et al. (2021) Safety and immunogenicity of SARS-CoV-2 variant mRNA vaccine boosters in healthy adults: an interim analysis. Nat Med 27:2025-2031.

Clover (Press release, September 22, 2021) Clover's COVID-19 vaccine candidate demonstrates $79 \%$ efficacy against Delta in global phase 2/3 SPECTRA tria dominated by variants of concern and interest. (http://www.cloverbiopharma.com/ news/83.html; accessed:September 30, 2021).

Cohen $J(2020)$ The race is on for antibodies that stop the new coronavirus. Science 368:564-565.

Cohen J (2021a) The dream vaccine. Science 372:227-231.

Cohen MS (2021b) Monoclonal antibodies to disrupt progression of early Covid-19 infection. $N$ Engl J Med 384:289-291.

Collier DA, De Marco A, Ferreira IATM, Meng B, Datir RP, Walls AC, Kemp SA Bassi J, Pinto D, Silacci-Fregni C, et al. (2021) Sensitivity to SARS-CoV-2 B.1.1.7 to mRNA vaccine-elicited antibodies. Nature 593:136-141.

Corbett KS, Flynn B, Foulds KE, Francica JR, Boyoglu-Barnum S, Werner AP, Flach B, O'Connell S, Bock KW, Minai M, et al. (2020) Evaluation of the mRNA1273 vaccine against SARS-CoV-2 in nonhuman primates. $N$ Engl $J$ Med 383:1544-1555.

Correia BE, Bates JT, Loomis RJ, Baneyx G, Carrico C, Jardine JG, Rupert P, Correnti C, Kalyuzhniy O, Vittal V, et al. (2014) Proof of principle for epitopefocused vaccine design. Nature 507:201-206.

Coutard B, Valle C, de Lamballerie X, Canard B, Seidah NG, and Decroly E (2020) The spike glycoprotein of the new coronavirus 2019-nCoV contains a furin-like cleavage site absent in $\mathrm{CoV}$ of the same clade. Antiviral Res 176:104742.

Crotty S (2021) Hybrid immunity. Science 372:1392-1393.

Cui J, Li F, and Shi ZL (2019) Origin and evolution of pathogenic coronaviruses. Nat Rev Microbiol 17:181-192.

CureVac (Press release, June 16, 2021) CureVac provides update on phase 2b/3 trial of first-generation COVID-19 vaccine candidate, CVnCoV. (http://www. curevac.com/en/2021/06/16/curevac-provides-update-on-phase-2b-3-trial-of-firstgeneration-covid-19-vaccine-candidate-cvncov/; accessed September 24, 2021).

Dai L and Gao GF (2021) Viral targets for vaccines against COVID-19. Nat Rev Immunol 21:73-82.
Dan JM, Mateus J, Kato Y, Hastie KM, Yu ED, Faliti CE, Grifoni A, Ramirez SI, Haupt S, Frazier A, et al. (2021) Immunological memory to SARS-CoV-2 assessed for up to 8 months after infection. Science 371:eabf4063.

Davies NG, Abbott S, Barnard RC, Jarvis CI, Kucharski AJ, Munday JD, Pearson CAB, Russell TW, Tully DC, Washburne AD, et al.; CMMID COVID-19 Working Group; COVID-19 Genomics UK (COG-UK) Consortium (2021) Estimated transmissibility and impact of SARS-CoV-2 lineage B.1.1.7 in England. Science 372:eabg3055.

Del Giudice G, Rappuoli R, and Didierlaurent AM (2018) Correlates of adjuvanticity: a review on adjuvants in licensed vaccines. Semin Immunol 39:14-21.

Dong Y, Dai T, Wei Y, Zhang L, Zheng M, and Zhou F (2020) A systematic review of SARS-CoV-2 vaccine candidates. Signal Transduct Target Ther 5:237.

Doria-Rose N, Suthar MS, Makowski M, O'Connell S, McDermott AB, Flach B, Ledgerwood JE, Mascola JR, Graham BS, Lin BC, et al.; mRNA-1273 Study Group (2021) Antibody persistence through 6 months after the second dose of mRNA-1273 vaccine for Covid-19. N Engl J Med 384:2259-2261.

Du L, He Y, Jiang S, and Zheng BJ (2008) Development of subunit vaccines against severe acute respiratory syndrome. Drugs Today (Barc) 44:63-73.

Earle KA, Ambrosino DM, Fiore-Gartland A, Goldblatt D, Gilbert PB, Siber GR, Dull P, and Plotkin SA (2021) Evidence for antibody as a protective correlate for COVID-19 vaccines. Vaccine 39:4423-4428.

Ella R, Reddy S, Jogdand H, Sarangi V, Ganneru B, Prasad S, Das D, Raju D, Praturi U, Sapkal G, et al. (2021) Safety and immunogenicity of an inactivated SARS-CoV-2 vaccine, BBV152: interim results from a double-blind, randomised, multicentre, phase 2 trial, and 3-month follow-up of a double-blind, randomised phase 1 trial. Lancet Infect Dis 21:950-961.

Emary KRW, Golubchik T, Aley PK, Ariani CV, Angus B, Bibi S, Blane B, Bonsall D, Cicconi P, Charlton S, et al.; COVID-19 Genomics UK consortium; AMPHEUS Project; Oxford COVID-19 Vaccine Trial Group (2021) Efficacy of ChAdOx1 nCoV-19 (AZD1222) vaccine against SARS-CoV-2 variant of concern 202012/01 (B.1.1.7): an exploratory analysis of a randomised controlled trial. Lancet 397:1351-1362.

Faria NR, Claro IM, Candido D, Moyses Franco LA, Andrade PS, Coletti TM, Silva CAM, Sales FC, Manuli ER, Aguiar RS, et al. (2021) Genomic characterisation of an emergent SARS-CoV-2 lineage in Manaus: preliminary findings. (http:// virological.org/t/genomic-characterisation-of-an-emergent-sars-cov-2-lineage-inmanaus-preliminary-findings/586).

Ferreira IATM, Kemp SA, Datir R, Saito A, Meng B, Rakshit P, Takaori-Kondo A, Kosugi Y, Uriu K, Kimura I, et al.; CITIID-NIHR BioResource COVID-19 Collaboration, Indian SARS-CoV-2 Genomics Consortium; Genotype to Phenotype Japan (G2P-Japan) Consortium (2021) SARS-CoV-2 B.1.617 mutations L452R and $\mathrm{E} 484 \mathrm{Q}$ are not synergistic for antibody evasion. J Infect Dis 224:989-994.

Folegatti PM, Ewer KJ, Aley PK, Angus B, Becker S, Belij-Rammerstorfer S, Bellamy D, Bibi S, Bittaye M, Clutterbuck EA, et al.; Oxford COVID Vaccine Trial Group (2020) Safety and immunogenicity of the ChAdOx1 nCoV-19 vaccine against SARS-CoV-2: a preliminary report of a phase $1 / 2$, single-blind, randomised controlled trial. Lancet 396:467-478.

Food and Drug Administration News Release (Press release, April 16, 2021a) Coronavirus (COVID-19) update: FDA revokes emergency use authorization for monoclonal antibody bamlanivimab. (http://www.fda.gov/news-events/press-announcements/coronaviruscovid-19-update-fda-revokes-emergency-use-authorization-monoclonal-antibodybamlanivimab; accessed: April 24, 2021.)

Food and Drug Administration (Press release, August 23, 2021b) FDA approve first COVID-19 vaccine. (http://www.fda.gov/news-events/press-announcements/ fda-approves-first-covid-19-vaccine; accessed: September 30, 2021).

Food and Drug Administration (Press release, September 22, 2021c) FDA authorizes booster dose of Pfizer-BioNTech COVID-19 vaccine for certain populations. (http:/ www.fda.gov/news-events/press-announcements/fda-authorizes-booster-dose-pfizerbiontech-covid-19-vaccine-certain-populations; accessed: September 30, 2021).

Francica JR, Flynn BJ, Foulds KE, Noe AT, Werner AP, Moore IN, Gagne M, Johnston TS, Tucker C, Davis RL, et al. (2021) Protective antibodies elicited by SARS-CoV-2 spike protein vaccination are boosted in the lung after challenge in nonhuman primates. Sci Transl Med 13:eabi4547.

Frenck Jr RW, Klein NP, Kitchin N, Gurtman A, Absalon J, Lockhart S, Perez JL Walter EB, Senders S, Bailey R, et al.; C4591001 Clinical Trial Group (2021) Safety, immunogenicity, and efficacy of the BNT162b2 Covid-19 vaccine in adolescents. N Engl J Med 385:239-250.

Gaebler C, Wang Z, Lorenzi JCC, Muecksch F, Finkin S, Tokuyama M, Cho A, Jankovic M, Schaefer-Babajew D, Oliveira TY, et al. (2021) Evolution of antibody immunity to SARS-CoV-2. Nature 591:639-644.

Gao Q, Bao L, Mao H, Wang L, Xu K, Yang M, Li Y, Zhu L, Wang N, Lv Z, et al. (2020) Development of an inactivated vaccine candidate for SARS-CoV-2. Science 369:77-81.

Garcia-Beltran WF, Lam EC, St Denis K, Nitido AD, Garcia ZH, Hauser BM, Feldman J, Pavlovic MN, Gregory DJ, Poznansky MC, et al. (2021) Multiple SARS-CoV-2 variants escape neutralization by vaccine-induced humoral immunity. Cell 184:2523.

Gebre MS, Rauch S, Roth N, Yu J, Chandrashekar A, Mercado NB, He X, Liu J, McMahan K, Martinot A, et al. (2021) Optimization of non-coding regions for a non-modified mRNA COVID-19 vaccine. Nature 10.1038/s41586-41021-04231-41586. Goel RR, Apostolidis SA, Painter MM, Mathew D, Pattekar A, Kuthuru O, Gouma S, Hicks P, Meng W, Rosenfeld AM, et al. (2021a) Distinct antibody and memory B cell responses in SARS-CoV-2 naïve and recovered individuals following mRNA vaccination. Sci Immunol 6:eabi6950.

Goel RR, Painter MM, Apostolidis SA, Mathew D, Meng W, Rosenfeld AM, Lundgreen KA, Reynaldi A, Khoury DS, Pattekar A, et al.; UPenn COVID Processing Unit: (2021b) mRNA vaccines induce durable immune memory to SARS-CoV-2 and variants of concern. Science 374:abm0829.

Goepfert PA, Fu B, Chabanon A-L, Bonaparte MI, Davis MG, Essink BJ, Frank I, Haney O, Janosczyk H, Keefer MC, et al. (2021) Safety and immunogenicity of 
SARS-CoV-2 recombinant protein vaccine formulations in healthy adults: interim results of a randomised, placebo-controlled, phase 1-2, dose-ranging study. Lancet Infect Dis 21:1257-1270.

Goldberg Y, Mandel M, Bar-On YM, Bodenheimer O, Freedman L, Haas EJ, Milo R, Alroy-Preis S, Ash N, and Huppert A (2021) Waning immunity after the BNT162b2 vaccine in Israel. $N$ Engl $J$ Med 385:e85.

Graham BS (2020) Rapid COVID-19 vaccine development. Science 368:945-946.

Greinacher A, Thiele T, Warkentin TE, Weisser K, Kyrle PA, and Eichinger S (2021) Thrombotic thrombocytopenia after ChAdOx1 nCov-19 vaccination. $N$ Engl J Med 384:2092-2101.

Grifoni A, Weiskopf D, Ramirez SI, Mateus J, Dan JM, Moderbacher CR, Rawlings SA, Sutherland A, Premkumar L, Jadi RS, et al. (2020) Targets of T cell responses to SARS-CoV-2 coronavirus in humans with COVID-19 disease and unexposed individuals. Cell 181:1489-1501.e15.

GSK (Press release, March 10, 2021) Vir Biotechnology and GSK announce VIR7831 reduces hospitalisation and risk of death in early treatment of adults with COVID-19. (http://www.gsk.com/en-gb/media/press-releases/vir-biotechnologyand-gsk-announce-vir-7831-reduces-hospitalisation-and-risk-of-death-in-earlytreatment-of-adults-with-covid-19/; accessed: April 24, 2021).

Guebre-Xabier M, Patel N, Tian JH, Zhou B, Maciejewski S, Lam K, Portnoff AD, Massare MJ, Frieman MB, Piedra PA, et al. (2020) NVX-CoV2373 vaccine protects cynomolgus macaque upper and lower airways against SARS-CoV-2 challenge. Vaccine 38:7892-7896.

Haas EJ, Angulo FJ, McLaughlin JM, Anis E, Singer SR, Khan F, Brooks N, Smaja M, Mircus G, Pan K, et al. (2021) Impact and effectiveness of mRNA BNT162b2 vaccine against SARS-CoV-2 infections and COVID-19 cases, hospitalisations, and deaths following a nationwide vaccination campaign in Israel: an observational study using national surveillance data. Lancet 397:1819-1829.

Hacisuleyman E, Hale C, Saito Y, Blachere NE, Bergh M, Conlon EG, SchaeferBabajew DJ, DaSilva J, Muecksch F, Gaebler C, et al. (2021) Vaccine breakthrough infections with SARS-CoV-2 variants. $N$ Engl J Med 384: 2212-2218.

Hansen J, Baum A, Pascal KE, Russo V, Giordano S, Wloga E, Fulton BO, Yan Y, Koon K, Patel K, et al. (2020) Studies in humanized mice and convalescent humans yield a SARS-CoV-2 antibody cocktail. Science 369:1010-1014.

Hillus D, Schwarz T, Tober-Lau P, Vanshylla K. Hastor H, Thibeault C, Jentzsch S, Helbig ET, Lippert LJ, Tscheak P, et al.; EICOV/COVIM Study Group (2021) Safety, reactogenicity, and immunogenicity of homologous and heterologous prime-boost immunisation with ChAdOx1 $\mathrm{nCoV}-19$ and BNT162b2: a prospective cohort study. Lancet Respir Med 9:1255-1265 10.1016/S2213-2600(1021)00357-X.

$\mathrm{Hu}$ B, Guo H, Zhou P, and Shi ZL (2021) Characteristics of SARS-CoV-2 and COVID-19. Nat Rev Microbiol 19:141-154.

Huang AT, Garcia-Carreras B, Hitchings MDT, Yang B, Katzelnick LC, Rattigan SM, Borgert BA, Moreno CA, Solomon BD, Trimmer-Smith L, et al. (2020a) A systematic review of antibody mediated immunity to coronaviruses: kinetics, correlates of protection, and association with severity. Nat Commun 11:4704.

Huang C, Wang Y, Li X, Ren L, Zhao J, Hu Y, Zhang L, Fan G, Xu J, Gu X, et al. (2020b) Clinical features of patients infected with 2019 novel coronavirus in Wuhan, China. Lancet 395:497-506.

Ibarrondo FJ, Fulcher JA, Goodman-Meza D, Elliott J, Hofmann C, Hausner MA, Ferbas KG, Tobin NH, Aldrovandi GM, and Yang OO (2020) Rapid decay of antiSARS-CoV-2 antibodies in persons with mild Covid-19. $N$ Engl J Med 383:1085-1087.

Ikegame S, Siddiquey MNA, Hung C-T, Haas G, Brambilla L, Oguntuyo KY, Kowdle S, Chiu HP, Stevens CS, Vilardo AE, et al. (2021) Neutralizing activity of Sputnik V vaccine sera against SARS-CoV-2 variants. Nat Commun 12:4598.

Isho B, Abe KT, Zuo M, Jamal AJ, Rathod B, Wang JH, Li Z, Chao G, Rojas OL, Bang YM, et al. (2020) Persistence of serum and saliva antibody responses to SARS-CoV-2 spike antigens in COVID-19 patients. Sci Immunol 5:eabe5511.

Iyer AS, Jones FK, Nodoushani A, Kelly M, Becker M, Slater D, Mills R, Teng E, Kamruzzaman M, Garcia-Beltran WF, et al. (2020) Persistence and decay of human antibody responses to the receptor binding domain of SARS-CoV-2 spike protein in COVID-19 patients. Sci Immunol 5:eabe0367.

Jackson LA, Anderson EJ, Rouphael NG, Roberts PC, Makhene M, Coler RN, McCullough MP, Chappell JD, Denison MR, Stevens LJ, et al.; mRNA-1273 Study Group (2020) An mRNA vaccine against SARS-CoV-2-Preliminary Report. N Engl J Med 383:1920-1931.

Jeyanathan M, Afkhami S, Smaill F, Miller MS, Lichty BD, and Xing Z (2020) Immunological considerations for COVID-19 vaccine strategies. Nat Rev Immunol 20:615-632.

Jiang C, Wang Y, Hu M, Wen L, Wen C, Wang Y, Zhu W, Tai S, Jiang Z, Xiao K et al. (2020) Antibody seroconversion in asymptomatic and symptomatic patients infected with severe acute respiratory syndrome coronavirus 2 (SARS-CoV-2). Clin Transl Immunology 9:e1182.

Jones BE, Brown-Augsburger PL, Corbett KS, Westendorf K, Davies J, Cujec TP, Wiethoff CM, Blackbourne JL, Heinz BA, Foster D, et al. (2021) The neutralizing antibody, LY-CoV555, protects against SARS-CoV-2 infection in nonhuman primates. Sci Transl Med 13:eabf1906.

Ju B, Zhang Q, Ge J, Wang R, Sun J, Ge X, Yu J, Shan S, Zhou B, Song S, et al. (2020) Human neutralizing antibodies elicited by SARS-CoV-2 infection. Nature 584:115-119.

Karikó K, Buckstein M, Ni H, and Weissman D (2005) Suppression of RNA recognition by toll-like receptors: the impact of nucleoside modification and the evolutionary origin of RNA. Immunity 23:165-175.

Karim SSA (2021) Vaccines and SARS-CoV-2 variants: the urgent need for a correlate of protection. Lancet 397:1263-1264.

Katz LM (2021) (A little) clarity on convalescent plasma for Covid-19. $N$ Engl $J$ Med 384:666-668.
Keech C, Albert G, Cho I, Robertson A, Reed P, Neal S, Plested JS, Zhu M, Cloney-Clark $\mathrm{S}$, Zhou H, et al. (2020) Phase 1-2 trial of a SARS-CoV-2 recombinant spike protein nanoparticle vaccine. N Engl J Med 383:2320-2332.

Kelley B (2020) Developing therapeutic monoclonal antibodies at pandemic pace. Nat Biotechnol 38:540-545.

Khoury DS, Cromer D, Reynaldi A, Schlub TE, Wheatley AK, Juno JA, Subbarao K, Kent SJ, Triccas JA, and Davenport MP (2021) Neutralizing antibody levels are highly predictive of immune protection from symptomatic SARS-CoV-2 infection. Nat Med 27:1205-1211.

Kim JH, Marks F, and Clemens JD (2021) Looking beyond COVID-19 vaccine phase 3 trials. Nat Med 27:205-211.

Ko JH, Müller MA, Seok H, Park GE, Lee JY, Cho SY, Ha YE, Baek JY, Kim SH, Kang JM, et al. (2017) Serologic responses of 42 MERS-coronavirus-infected patients according to the disease severity. Diagn Microbiol Infect Dis 89:106-111.

Korber B, Fischer WM, Gnanakaran S, Yoon H, Theiler J, Abfalterer W, Hengartner N, Giorgi EE, Bhattacharya T, Foley B, et al.; Sheffield COVID-19 Genomics Group (2020) Tracking changes in SARS-CoV-2 spike: evidence that D614G increases infectivity of the COVID-19 virus. Cell 182:812-827.e19.

Korompoki E, Gavriatopoulou M, Hicklen RS, Ntanasis-Stathopoulos I, Kastritis E, Fotiou D, Stamatelopoulos K, Terpos E, Kotanidou A, Hagberg CA, et al. (2021) Epidemiology and organ specific sequelae of post-acute COVID-19: a narrative review. J Infect 83:1-16.

Koyama T, Platt D, and Parida L (2020) Variant analysis of SARS-CoV-2 genomes. Bull World Health Organ 98:495-504.

Krammer F (2020) SARS-CoV-2 vaccines in development. Nature 586:516-527.

Krammer F, Srivastava K, Alshammary H, Amoako AA, Awawda MH, Beach KF, Bermúdez-González MC, Bielak DA, Carreño JM, Chernet RL, et al. (2021) Antibody responses in seropositive persons after a single dose of SARS-CoV-2 mRNA vaccine. $N$ Engl J Med 384:1372-1374.

Krause P, Fleming TR, Longini I, Henao-Restrepo AM, and Peto R; World Health Organization Solidarity Vaccines Trial Expert Group (2020) COVID-19 vaccine trials should seek worthwhile efficacy. Lancet 396:741-743.

Kreer C, Zehner M, Weber T, Ercanoglu MS, Gieselmann L, Rohde C, Halwe S, Korenkov M, Schommers P, Vanshylla K, et al. (2020) Longitudinal isolation of potent near-germline SARS-CoV-2-neutralizing antibodies from COVID-19 patients. Cell 182:843-854.e12.

Kremsner PG, Mann P, Kroidl A, Leroux-Roels I, Schindler C, Gabor JJ, Schunk M, Leroux-Roels G, Bosch JJ, Fendel R, et al.; CV-NCOV-001 Study Group (2021) Safety and immunogenicity of an mRNA-lipid nanoparticle vaccine candidate against SARS-CoV-2 : a phase 1 randomized clinical trial. Wien Klin Wochenschr 133:931-941.

Laiton-Donato K, Franco-Muñoz C, Álvarez-Díaz DA, Ruiz-Moreno HA, Usme-Ciro JA, Prada DA, Reales-González J, Corchuelo S, Herrera-Sepúlveda MT, Naizaque J, et al. (2021) Characterization of the emerging B.1.621 variant of interest of SARS-CoV-2. Infect Genet Evol 95:105038.

Lan J, Ge J, Yu J, Shan S, Zhou H, Fan S, Zhang Q, Shi X, Wang Q, Zhang L, et al. (2020) Structure of the SARS-CoV-2 spike receptor-binding domain bound to the ACE2 receptor. Nature 581:215-220.

Le Bert N, Tan AT, Kunasegaran K, Tham CYL, Hafezi M, Chia A, Chng MHY, Lin M, Tan N, Linster M, et al. (2020) SARS-CoV-2-specific T cell immunity in cases of COVID-19 and SARS, and uninfected controls. Nature 584:457-462.

Ledford H (2021) COVID vaccines and blood clots: five key questions. Nature 592:495-496.

Levin EG, Lustig Y, Cohen C, Fluss R, Indenbaum V, Amit S, Doolman R, Asraf K, Mendelson E, Ziv A, et al. (2021) Waning immune humoral response to BNT162b2 Covid-19 vaccine over 6 months. N Eng J Med 385:e84

Li B, Deng A, Li K, Hu Y, Li Z, Xiong Q, Liu Z, Guo Q, Zou L, Zhang H, et al. (2021) Viral infection and transmission in a large, well-traced outbreak caused by the SARS-CoV-2 Delta variant. (http://virological.org/t/viral-infection-and-transmissionin-a-large-well-traced-outbreak-caused-by-the-delta-sars-cov-2-variant/724).

Li Q, Wu J, Nie J, Zhang L, Hao H, Liu S, Zhao C, Zhang Q, Liu H, Nie L, et al. (2020a) The Impact of mutations in SARS-CoV-2 spike on viral infectivity and antigenicity. Cell 182:1284-1294.e9.

Li YD, Chi WY, Su JH, Ferrall L, Hung CF, and Wu TC (2020b) Coronavirus vaccine development: from SARS and MERS to COVID-19. J Biomed Sci 27:104.

Liu SJ, Leng CH, Lien SP, Chi HY, Huang CY, Lin CL, Lian WC, Chen CJ, Hsieh SL, and Chong P (2006) Immunological characterizations of the nucleocapsid protein based SARS vaccine candidates. Vaccine 24:3100-3108.

Liu STH, Lin HM, Baine I, Wajnberg A, Gumprecht JP, Rahman F, Rodriguez D Tandon P, Bassily-Marcus A, Bander J, et al. (2020a) Convalescent plasma treatment of severe COVID-19: a propensity score-matched control study. Nat Med 26:1708-1713.

Liu Y, Liu J, Xia H, Zhang X, Fontes-Garfias CR, Swanson KA, Cai H, Sarkar R, Chen W, Cutler M, et al. (2021) Neutralizing activity of BNT162b2-elicited serum. N Engl J Med 384:1466-1468.

Liu Y, Mao B, Liang S, Yang J-W, Lu H-W, Chai Y-H, Wang L, Zhang L, Li Q-H, Zhao L, et al.; Shanghai Clinical Treatment Experts Group for COVID-19 (2020b) Association between age and clinical characteristics and outcomes of COVID-19. Eur Respir J 55:2001112.

Liu Y and Rocklöv J (2021) The reproductive number of the Delta variant of SARS$\mathrm{CoV}-2$ is far higher compared to the ancestral SARS-CoV-2 virus. $J$ Travel Med 28:taab124.

Logunov DY, Dolzhikova IV, Shcheblyakov DV, Tukhvatulin AI, Zubkova OV, Dzharullaeva AS, Kovyrshina AV, Lubenets NL, Grousova DM, Erokhova AS, et al.; Gam-COVID-Vac Vaccine Trial Group (2021) Safety and efficacy of an rAd26 and rAd5 vector-based heterologous prime-boost COVID-19 vaccine: an interim analysis of a randomised controlled phase 3 trial in Russia. Lancet 397:671-681.

Logunov DY, Dolzhikova IV, Zubkova OV, Tukhvatullin AI, Shcheblyakov DV, Dzharullaeva AS, Grousova DM, Erokhova AS, Kovyrshina AV, Botikov AG, 
et al. (2020) Safety and immunogenicity of an rAd26 and rAd5 vector-based heterologous prime-boost COVID-19 vaccine in two formulations: two open, nonrandomised phase 1/2 studies from Russia. Lancet 396:887-897.

Long QX, Tang XJ, Shi QL, Li Q, Deng HJ, Yuan J, Hu JL, Xu W, Zhang Y, Lv FJ, et al. (2020) Clinical and immunological assessment of asymptomatic SARS-CoV2 infections. Nat Med 26:1200-1204.

Lopez Bernal J, Andrews N, Gower C, Gallagher E, Simmons R, Thelwall S, Stowe J, Tessier E, Groves N, Dabrera G, et al. (2021) Effectiveness of Covid-19 vaccines against the B.1.617.2 (Delta) variant. N Engl J Med 385:585-594.

Lou B, Li TD, Zheng SF, Su YY, Li ZY, Liu W, Yu F, Ge SX, Zou QD, Yuan Q, et al (2020) Serology characteristics of SARS-CoV-2 infection after exposure and postsymptom onset. Eur Respir J 56:2000763.

Low JS, Vaqueirinho D, Mele F, Foglierini M, Jerak J, Perotti M, Jarrossay D, Jovic S, Perez L, Cacciatore R, et al. (2021) Clonal analysis of immunodominance and cross-reactivity of the CD4 T cell response to SARS-CoV-2. Science 372:1336-1341.

Lund FE and Randall TD (2021) Scent of a vaccine. Science 373:397-399.

Madhi SA, Baillie V, Cutland CL, Voysey M, Koen AL, Fairlie L, Padayachee SD, Dheda K, Barnabas SL, Bhorat QE, et al.; NGS-SA Group; Wits-VIDA COVID Group (2021) Efficacy of the ChAdOx1 nCoV-19 Covid-19 vaccine against the B.1.351 variant. $N$ Engl J Med 384:1885-1898.

Malherbe DC, Kurup D, Wirblich C, Ronk AJ, Mire C, Kuzmina N, Shaik N, Periasamy S, Hyde MA, Williams JM, et al. (2021) A single dose of replicationcompetent VSV-vectored vaccine expressing SARS-CoV-2 S1 protects against virus replication in a hamster model of severe COVID-19. NPJ Vaccines 6:91.

Marcandalli J, Fiala B, Ols S, Perotti M, de van der Schueren W, Snijder J, Hodge E, Benhaim M, Ravichandran R, Carter L, et al. (2019) Induction of potent neutralizing antibody responses by a designed protein nanoparticle vaccine for respiratory syncytial virus. Cell 176:1420-1431.e17.

Marovich M, Mascola JR, and Cohen MS (2020) Monoclonal antibodies for prevention and treatment of COVID-19. JAMA 324:131-132.

Martinon F, Krishnan S, Lenzen G, Magné R, Gomard E, Guillet J-G, Lévy J-P, and Meulien P (1993) Induction of virus-specific cytotoxic T lymphocytes in vivo by liposome-entrapped mRNA. Eur J Immunol 23:1719-1722.

Mascola JR, Graham BS, and Fauci AS (2021) SARS-CoV-2 viral variantstackling a moving target. JAMA 325:1261-1262.

McCallum M, De Marco A, Lempp FA, Tortorici MA, Pinto D, Walls AC, Beltramello M, Chen A, Liu Z, Zatta F, et al. (2021) N-terminal domain antigenic mapping reveals a site of vulnerability for SARS-CoV-2. Cell 184:2332-2347.e16.

McLellan JS, Chen M, Joyce MG, Sastry M, Stewart-Jones GBE, Yang Y, Zhang B, Chen L, Srivatsan S, Zheng A, et al. (2013a) Structure-based design of a fusion glycoprotein vaccine for respiratory syncytial virus. Science 342:592-598.

McLellan JS, Chen M, Leung S, Graepel KW, Du X, Yang Y, Zhou T, Baxa U, Yasuda E, Beaumont T, et al. (2013b) Structure of RSV fusion glycoprotein trimer bound to a prefusion-specific neutralizing antibody. Science $\mathbf{3 4 0}$ $1113-1117$

McMahan K, Yu J, Mercado NB, Loos C, Tostanoski LH, Chandrashekar A, Liu J, Peter L, Atyeo C, Zhu A, et al. (2021) Correlates of protection against SARS-CoV2 in rhesus macaques. Nature 590:630-634.

Meng B, Kemp SA, Papa G, Datir R, Ferreira IATM, Marelli S, Harvey WT, Lytras S, Mohamed A, Gallo G, et al.; COVID-19 Genomics UK (COG-UK) Consortium (2021) Recurrent emergence of SARS-CoV-2 spike deletion H69/V70 and its role in the Alpha variant B.1.1.7. Cell Rep 35:109292.

Mercado NB, Zahn R, Wegmann F, Loos C, Chandrashekar A, Yu J, Liu J, Peter L, McMahan K, Tostanoski LH, et al. (2020) Single-shot Ad26 vaccine protects against SARS-CoV-2 in rhesus macaques. Nature 586:583-588.

Mizrahi B, Lotan R, Kalkstein N, Peretz A, Perez G, Ben-Tov A, Chodick G, Gazit $\mathrm{S}$, and Patalon T (2021) Correlation of SARS-CoV-2 breakthrough infections to time-from-vaccine; preliminary study. Nat Commun 12:6379.

Mlcochova P, Kemp S, Dhar MS, Papa G, Meng B, Ferreira IATM, Datir R, Collier DA, Albecka A, Singh S, et al.; Indian SARS-CoV-2 Genomics Consortium; Genotype to Phenotype Japan Consortium; CITIID-NIHR BioResource COVID-19 Collaboration (2021) SARS-CoV-2 B.1.617.2 Delta variant replication and immune evasion. Nature 599:114-119.

Mulligan MJ, Lyke KE, Kitchin N, Absalon J, Gurtman A, Lockhart S, Neuzil K, Raabe V, Bailey R, Swanson KA, et al. (2020) Phase I/II study of COVID-19 RNA vaccine BNT162b1 in adults. Nature 586:589-593.

Naaber P, Tserel L, Kangro K, Sepp E, Jürjenson V, Adamson A, Haljasmägi L, Rumm AP, Maruste R, Kärner J, et al. (2021) Dynamics of antibody response to BNT162b2 vaccine after six months: a longitudinal prospective study Lancet Reg Health Eur 10:100208.

Nathan A, Rossin EJ, Kaseke C, Park RJ, Khatri A, Koundakjian D, Urbach JM, Singh NK, Bashirova A, Tano-Menka R, et al. (2021) Structure-guided T cell vaccine design for SARS-CoV-2 variants and sarbecoviruses. Cell 184:4401-4413.e10.

Naveca F, Nascimento V, Souza V, Corado A, Nascimento F, Silva G, Costa A Duarte D, Pessoa K, and Gonçalves L (2021) Phylogenetic relationship of SARSCoV-2 sequences from Amazonas with emerging Brazilian variants harboring mutations $\mathrm{E} 484 \mathrm{~K}$ and $\mathrm{N} 501 \mathrm{Y}$ in the spike protein. (http://virological.org/t/ phylogenetic-relationship-of-sars-cov-2-sequences-from-amazonas-with-emergingbrazilian-variants-harboring-mutations-e484k-and-n501y-in-the-spike-protein/585).

Nelde A, Bilich T, Heitmann JS, Maringer Y, Salih HR, Roerden M, Lübke M, Bauer J, Rieth J, Wacker M, et al. (2021) SARS-CoV-2-derived peptides define heterologous and COVID-19-induced T cell recognition. Nat Immunol 22:74-85.

Ni L, Ye F, Cheng ML, Feng Y, Deng YQ, Zhao H, Wei P, Ge J, Gou M, Li X, et al. (2020) Detection of SARS-CoV-2-specific humoral and cellular immunity in COVID-19 convalescent individuals. Immunity 52:971-977.e3.

Norman M, Gilboa T, Ogata AF, Maley AM, Cohen L, Busch EL, Lazarovits R, Mao CP, Cai Y, Zhang J, et al. (2020) Ultrasensitive high-resolution profiling of early seroconversion in patients with COVID-19. Nat Biomed Eng 4:1180-1187.
Novavax (Press release, January 28, 2021) Novavax COVID-19 vaccine demonstrates $89.3 \%$ efficacy in UK phase 3 trial. (https://ir.novavax.com/2021-01-28-NovavaxCOVID-19-Vaccine-Demonstrates-89-3-Efficacy-in-UK-Phase-3-Trial; accessed: April 24, 2021).

Oberhardt V, Luxenburger H, Kemming J, Schulien I, Ciminski K, Giese S, Csernalabics B, Lang-Meli J, Janowska I, Staniek J, et al. (2021) Rapid and stable mobilization of $\mathrm{CD}^{+}{ }^{+} \mathrm{T}$ cells by SARS-CoV-2 mRNA vaccine. Nature 597:268-273.

Okba NMA, Müller MA, Li W, Wang C, GeurtsvanKessel CH, Corman VM, Lamers MM, Sikkema RS, de Bruin E, Chandler FD, et al. (2020) Severe acute respiratory syndrome coronavirus 2 -specific antibody responses in coronavirus disease patients. Emerg Infect Dis 26:1478-1488.

Ozono S, Zhang Y, Ode H, Sano K, Tan TS, Imai K, Miyoshi K, Kishigami S, Ueno T, Iwatani Y, et al. (2021) SARS-CoV-2 D614G spike mutation increases entry efficiency with enhanced ACE2-binding affinity. Nat Commun 12:848.

Padoan A, Sciacovelli L, Basso D, Negrini D, Zuin S, Cosma C, Faggian D, Matricardi P, and Plebani M (2020) IgA-Ab response to spike glycoprotein of SARS-CoV-2 in patients with COVID-19: a longitudinal study. Clin Chim Acta 507:164-166.

Pallesen J, Wang N, Corbett KS, Wrapp D, Kirchdoerfer RN, Turner HL, Cottrell CA, Becker MM, Wang L, Shi W, et al. (2017) Immunogenicity and structures of a rationally designed prefusion MERS-CoV spike antigen. Proc Natl Acad Sci USA 114:E7348-E7357.

PANGO (2021) Global report investigating novel coronavirus haplotypes. (http:// cov-lineages.org/global_report.html; accessed: April 7, 2021).

Pardi N, Hogan MJ, Porter FW, and Weissman D (2018) mRNA vaccines-a new era in vaccinology. Nat Rev Drug Discov 17:261-279.

Park M, Thwaites RS, and Openshaw PJM (2020) COVID-19: lessons from SARS and MERS. Eur J Immunol 50:308-311.

Pattabiraman C, Prasad P, George AK, Sreenivas D, Rasheed R, Reddy NVK, Desai A, and Vasanthapuram R (2021) Importation, circulation, and emergence of variants of SARS-CoV-2 in the South Indian State of Karnataka. Wellcome Open Res 6:110.

Peacock TP, Goldhill DH, Zhou J, Baillon L, Frise R, Swann OC, Kugathasan R, Penn R, Brown JC, Sanchez-David RY, et al. (2021) The furin cleavage site in the SARS-CoV-2 spike protein is required for transmission in ferrets. Nat Microbiol 6:899-909.

Peng Y, Mentzer AJ, Liu G, Yao X, Yin Z, Dong D, Dejnirattisai W, Rostron T, Supasa P, Liu C, et al.; Oxford Immunology Network Covid-19 Response T cell Consortium; ISARIC4C Investigators (2020) Broad and strong memory CD4 ${ }^{+}$ and $\mathrm{CD}^{+}{ }^{+} \mathrm{T}$ cells induced by SARS-CoV-2 in UK convalescent individuals following COVID-19. Nat Immunol 21:1336-1345.

Piccoli L, Park YJ, Tortorici MA, Czudnochowski N, Walls AC, Beltramello M, Silacci-Fregni C, Pinto D, Rosen LE, Bowen JE, et al. (2020) Mapping neutralizing and immunodominant sites on the SARS-CoV-2 spike receptor-binding domain by structure-guided high-resolution serology. Cell 183:1024-1042.e21.

Pilishvili T, Gierke R, Fleming-Dutra KE, Farrar JL, Mohr NM, Talan DA, Krishnadasan A, Harland KK, Smithline HA, Hou PC, et al.; Vaccine Effectiveness among Healthcare Personnel Study Team (2021) Effectiveness of mRNA Covid-19 vaccine among U.S. health care personnel. $N$ Engl J Med 385: 90 .

Pinto D, Park YJ, Beltramello M, Walls AC, Tortorici MA, Bianchi S, Jaconi S, Culap K, Zatta F, De Marco A, et al. (2020) Cross-neutralization of SARS-CoV-2 by a human monoclonal SARS-CoV antibody. Nature 583:290-295.

Planas D, Veyer D, Baidaliuk A, Staropoli I, Guivel-Benhassine F, Rajah MM Planchais C, Porrot F, Robillard N, Puech J, et al. (2021) Reduced sensitivity of SARS-CoV-2 variant Delta to antibody neutralization. Nature 596:276-280.

Polack FP, Thomas SJ, Kitchin N, Absalon J, Gurtman A, Lockhart S, Perez JL, Pérez Marc G, Moreira ED, Zerbini C, et al.; C4591001 Clinical Trial Group (2020) Safety and efficacy of the BNT162b2 mRNA Covid-19 vaccine. $N$ Engl J Med 383:2603-2615.

Poland GA, Ovsyannikova IG, and Kennedy RB (2020) SARS-CoV-2 immunity: review and applications to phase 3 vaccine candidates. Lancet 396:1595-1606.

Pollard AJ, Launay O, Lelievre JD, Lacabaratz C, Grande S, Goldstein N, Robinson C, Gaddah A, Bockstal V, Wiedemann A, et al.; EBOVAC2 EBL2001 study group (2021) Safety and immunogenicity of a two-dose heterologous Ad26.ZEBOV and MVA-BN-Filo Ebola vaccine regimen in adults in Europe (EBOVAC2): a randomised, observer-blind, participant-blind, placebo-controlled, phase 2 trial. Lancet Infect Dis 21:493-506.

Pouwels KB, Pritchard E, Matthews PC, Stoesser N, Eyre DW, Vihta K-D, House T, Hay J, Bell JI, Newton JN, et al. (2021) Effect of Delta variant on viral burden and vaccine effectiveness against new SARS-CoV-2 infections in the UK. Nat Med 27:2127-2135

Premkumar L, Segovia-Chumbez B, Jadi R, Martinez DR, Raut R, Markmann A Cornaby C, Bartelt L, Weiss S, Park Y, et al. (2020) The receptor binding domain of the viral spike protein is an immunodominant and highly specific target of antibodies in SARS-CoV-2 patients. Sci Immunol 5:eabc8413.

Prendecki M, Clarke C, Brown J, Cox A, Gleeson S, Guckian M, Randell P, Pria AD, Lightstone L, Xu XN, et al. (2021) Effect of previous SARS-CoV-2 infection on humoral and T-cell responses to single-dose BNT162b2 vaccine. Lancet 397:1178-1181.

Public Health England (2020) Investigation of novel SARS-COV-2 variant: variant of Concern 202012/01. (http://assets.publishing.service.gov.uk/government/uploads/system/ uploads/attachment_data/file/959438/Technical_Briefing_VOC_SH_NJL2_SH2. pdf; accessed: April 24, 2021).

Public Health England (2021) Investigation of novel SARS-CoV-2 variant: variant of Concern 202012/01. Technical briefing 5. (http://assets.publishing.service.gov. uk/government/uploads/system/uploads/attachment_data/file/959426/Variant_of_ Concern_VOC_202012_01_Technical_Briefing_5.pdf; accessed on April 24, 2021). 
Pulendran B, S Arunachalam PS, and O'Hagan DT (2021) Emerging concepts in the science of vaccine adjuvants. Nat Rev Drug Discov 20:454-475.

Ragab D, Salah Eldin H, Taeimah M, Khattab R, and Salem R (2020) The COVID19 cytokine storm; what we know so far. Front Immunol 11:1446.

Rambaut A, Holmes EC, O'Toole Á, Hill V, McCrone JT, Ruis C, du Plessis L, and Pybus OG (2020) A dynamic nomenclature proposal for SARS-CoV-2 lineages to assist genomic epidemiology. Nat Microbiol 5:1403-1407.

Rappuoli R, De Gregorio E, Del Giudice G, Phogat S, Pecetta S, Pizza M, and Hanon E (2021) Vaccinology in the post-COVID-19 era. Proc Natl Acad Sci USA 118:e2020368118.

Rees-Spear C, Muir L, Griffith SA, Heaney J, Aldon Y, Snitselaar JL, Thomas P, Graham C, Seow J, Lee N, et al.; SAFER Investigators (2021) The effect of spike mutations on SARS-CoV-2 neutralization. Cell Rep 34:108890.

Renn A, Fu Y, Hu X, Hall MD, and Simeonov A (2020) Fruitful Neutralizing Antibody Pipeline Brings Hope To Defeat SARS-Cov-2. Trends Pharmacol Sci 41:815-829.

Reynolds CJ, Pade C, Gibbons JM, Butler DK, Otter AD, Menacho K, Fontana M, Smit A, Sackville-West JE, Cutino-Moguel T, et al.; UK COVIDsortium Immune Correlates Network; UK COVIDsortium Investigators (2021) Prior SARS-CoV-2 infection rescues $\mathrm{B}$ and $\mathrm{T}$ cell responses to variants after first vaccine dose. Science 372:1418-1423.

Richmond P, Hatchuel L, Dong M, Ma B, Hu B, Smolenov I, Li P, Liang P, Han HH, Liang J, et al. (2021) Safety and immunogenicity of S-Trimer (SCB-2019), a protein subunit vaccine candidate for COVID-19 in healthy adults: a phase 1 , randomised, double-blind, placebo-controlled trial. Lancet 397:682-694.

Rogers TF, Zhao F, Huang D, Beutler N, Burns A, He WT, Limbo O, Smith C, Song $\mathrm{G}$, Woehl J, et al. (2020) Isolation of potent SARS-CoV-2 neutralizing antibodies and protection from disease in a small animal model. Science 369:956-963.

Rydyznski Moderbacher C, Ramirez SI, Dan JM, Grifoni A, Hastie KM, Weiskopf D, Belanger S, Abbott RK, Kim C, Choi J, et al. (2020) Antigen-specific adaptive immunity to SARS-CoV-2 in acute COVID-19 and associations with age and disease severity. Cell 183:996-1012.e19.

Sabino EC, Buss LF, Carvalho MPS, Prete Jr CA, Crispim MAE, Fraiji NA, Pereira RHM, Parag KV, da Silva Peixoto P, Kraemer MUG, et al. (2021) Resurgence of COVID-19 in Manaus, Brazil, despite high seroprevalence. Lancet 397:452-455.

Sadoff J, Gray G, Vandebosch A, Cárdenas V, Shukarev G, Grinsztejn B, Goepfert PA, Truyers C, Fennema H, Spiessens B, et al.; ENSEMBLE Study Group (2021a) Safety and efficacy of single-dose Ad26.COV2.S vaccine against Covid-19. N Engl J Med 384:2187-2201.

Sadoff J, Le Gars M, Shukarev G, Heerwegh D, Truyers C, de Groot AM, Stoop J, Tete S, Van Damme W, Leroux-Roels I, et al. (2021b) Interim results of a phase 1-2a trial of Ad26.COV2.S Covid-19 vaccine. N Engl J Med 384:1824-1835.

Sahin U, Muik A, Derhovanessian E, Vogler I, Kranz LM, Vormehr M, Baum A, Pascal K, Quandt J, Maurus D, et al. (2020) COVID-19 vaccine BNT162b1 elicits human antibody and $\mathrm{T}_{\mathrm{H}} 1 \mathrm{~T}$ cell responses. Nature 586:594-599.

Samarasekera U (2021) CEPI prepares for future pandemics and epidemics. Lancet Infect Dis 21:608.

Sanchez-Felipe L, Vercruysse T, Sharma S, Ma J, Lemmens V, Van Looveren D, Arkalagud Javarappa MP, Boudewijns R, Malengier-Devlies B, Liesenborghs L, et al. (2021) A single-dose live-attenuated YF17D-vectored SARS-CoV-2 vaccine candidate. Nature 590:320-325.

Sanofi (Press release, May 17, 2021) Sanofi and GSK COVID-19 vaccine candidate demonstrates strong immune responses across all adult age groups in Phase 2 trial. (http://www.sanofi.com/en/media-room/press-releases/2021/2021-05-17-07 30-00-2230312\#; accessed: September 24, 2021).

Santa Cruz A, Mendes-Frias A, Oliveira AI, Dias L, Matos AR, Carvalho A, Capela C, Pedrosa J, Castro AG, and Silvestre R (2021) Interleukin-6 is a biomarker for the development of fatal severe acute respiratory syndrome coronavirus 2 pneumonia. Front Immunol 12:613422.

Sariol A and Perlman S (2020) Lessons for COVID-19 immunity from other coronavirus infections. Immunity 53:248-263.

Schäfer A, Muecksch F, Lorenzi JCC, Leist SR, Cipolla M, Bournazos S, Schmidt F, Maison RM, Gazumyan A, Martinez DR, et al. (2021) Antibody potency, effector function, and combinations in protection and therapy for SARS-CoV-2 infection in vivo. J Exp Med 218:e20201993.

Schoeman D and Fielding BC (2019) Coronavirus envelope protein: current knowledge. Virol J 16:69.

Scientific Pandemic Influenza Group on Modelling Operational subgroup (2021) SPI-M-O: consensus statement on COVID-19. (http://assets.publishing.service gov.uk/government/uploads/system/uploads/attachment_data/file/993321/S1267_SPIM-O_Consensus_Statement.pdf; accessed: September 22, 2021.

Sekine T, Perez-Potti A, Rivera-Ballesteros O, Strålin K, Gorin JB, Olsson A, Llewellyn-Lacey S, Kamal H, Bogdanovic G, Muschiol S, et al.; Karolinska COVID-19 Study Group (2020) Robust T cell immunity in convalescent individuals with asymptomatic or mild COVID-19. Cell 183:158-168.e14.

Sette A and Crotty S (2020) Pre-existing immunity to SARS-CoV-2: the knowns and unknowns. Nat Rev Immunol 20:457-458.

Shrotri M, Navaratnam AMD, Nguyen V, Byrne T, Geismar C, Fragaszy E, Beale S, Fong WLE, Patel P, Kovar J, et al.; Virus Watch Collaborative (2021) Spikeantibody waning after second dose of BNT162b2 or ChAdOx1. Lancet 398:385-387.

Singh D and Yi SV (2021) On the origin and evolution of SARS-CoV-2. Exp Mol Med 53:537-547.

Song W, Gui M, Wang X, and Xiang Y (2018) Cryo-EM structure of the SARS coronavirus spike glycoprotein in complex with its host cell receptor ACE2. PLoS Pathog 14:e1007236.

Stamatatos L, Czartoski J, Wan YH, Homad LJ, Rubin V, Glantz H, Neradilek M, Seydoux E, Jennewein MF, MacCamy AJ, et al. (2021) mRNA vaccination boosts cross-variant neutralizing antibodies elicited by SARS-CoV-2 infection. Science 372:1413-1418.
Starr TN, Greaney AJ, Hilton SK, Ellis D, Crawford KHD, Dingens AS, Navarro MJ, Bowen JE, Tortorici MA, Walls AC, et al. (2020) Deep mutational scanning of SARS-CoV-2 receptor binding domain reveals constraints on folding and ACE2 binding. Cell 182:1295-1310.e20.

Su S, Wong G, Shi W, Liu J, Lai ACK, Zhou J, Liu W, Bi Y, and Gao GF (2016) Epidemiology, genetic recombination, and pathogenesis of coronaviruses. Trends Microbiol 24:490-502.

Sudre CH, Murray B, Varsavsky T, Graham MS, Penfold RS, Bowyer RC, Pujol JC, Klaser K, Antonelli M, Canas LS, et al. (2021) Attributes and predictors of long COVID. Nat Med 27:626-631.

Sun H, Li Y, Liu P, Qiao C, Wang X, Wu L, Liu K, Hu Y, Su C, Tan S, et al. (2020a) Structural basis of HCoV-19 fusion core and an effective inhibition peptide against virus entry. Emerg Microbes Infect 9:1238-1241.

Sun J, Zhuang Z, Zheng J, Li K, Wong RL, Liu D, Huang J, He J, Zhu A, Zhao J, et al. (2020b) Generation of a broadly useful model for COVID-19 pathogenesis, vaccination, and treatment. Cell 182:734-743.e5.

Tan AT, Linster M, Tan CW, Le Bert N, Chia WN, Kunasegaran K, Zhuang Y, Tham CYL, Chia A, Smith GJD, et al. (2021) Early induction of functional SARSCoV-2-specific $\mathrm{T}$ cells associates with rapid viral clearance and mild disease in COVID-19 patients. Cell Rep 34:108728.

Tang P, Hasan MR, Chemaitelly H, Yassine HM, Benslimane FM, Al Khatib HA AlMukdad S, Coyle P, Ayoub HH, Kanaani ZA, et al. (2021) BNT162b2 and mRNA-1273 COVID-19 vaccine effectiveness against the Delta (B.1.617.2) variant in Qatar. Nat Med 27:2136-2143.

Tanriover MD, Doğanay HL, Akova M, Güner HR, Azap A, Akhan S, Köse S, Erdinç FS, Akalın EH, Tabak ÖF, et al.; CoronaVac Study Group (2021) Efficacy and safety of an inactivated whole-virion SARS-CoV-2 vaccine (CoronaVac): interim results of a double-blind, randomised, placebo-controlled, phase 3 trial in Turkey. Lancet 398:213-222.

Taylor PC, Adams AC, Hufford MM, de la Torre I, Winthrop K, and Gottlieb RL (2021) Neutralizing monoclonal antibodies for treatment of COVID-19. Nat Rev Immunol 21:382-393.

Tebas P, Yang S, Boyer JD, Reuschel EL, Patel A, Christensen-Quick A, Andrade VM, Morrow MP, Kraynyak K, Agnes J, et al. (2021) Safety and immunogenicity of INO-4800 DNA vaccine against SARS-CoV-2: a preliminary report of an openlabel, phase 1 clinical trial. EClinicalMedicine 31:100689.

Tegally H, Wilkinson E, Giovanetti M, Iranzadeh A, Fonseca V, Giandhari J, Doolabh D, Pillay S, San EJ, Msomi N, et al. (2021a) Detection of a SARS-CoV-2 variant of concern in South Africa. Nature 592:438-443.

Tegally H, Wilkinson E, Lessells RJ, Giandhari J, Pillay S, Msomi N, Mlisana K, Bhiman JN, von Gottberg A, Walaza S, et al. (2021b) Sixteen novel lineages of SARS-CoV-2 in South Africa. Nat Med 27:440-446.

Teyssou E, Delagrèverie H, Visseaux B, Lambert-Niclot S, Brichler S, Ferre V, Marot S, Jary A, Todesco E, Schnuriger A, et al. (2021) The Delta SARS-CoV-2 variant has a higher viral load than the Beta and the historical variants in nasopharyngeal samples from newly diagnosed COVID-19 patients. J Infect 83:e1-e3.

Thomas S.J, Moreira Jr ED, Kitchin N, Absalon J, Gurtman A, Lockhart S, Perez JL, Pérez Marc G, Polack FP, Zerbini C, et al.; C4591001 Clinical Trial Group (2021) Safety and efficacy of the BNT162b2 mRNA Covid-19 vaccine through 6 months. $N$ Engl J Med 385:1761-1773.

Tizard IR (2020) Vaccination against coronaviruses in domestic animals. Vaccine 38:5123-5130.

Tortorici MA, Beltramello M, Lempp FA, Pinto D, Dang HV, Rosen LE, McCallum M, Bowen J, Minola A, Jaconi S, et al. (2020) Ultrapotent human antibodies protect against SARS-CoV-2 challenge via multiple mechanisms. Science 370:950-957.

U.S. Food and Drug Administration (Press release, May 26, 2021) Coronavirus (COVID-19) update: FDA authorizes additional monoclonal antibody for treatment of COVID-19. (http://www.fda.gov/news-events/press-announcements/coronaviruscovid-19-update-fda-authorizes-additional-monoclonal-antibody-treatment-covid-19; accessed: September 24, 2021).

Ulmer JB, Donnelly JJ, Parker SE, Rhodes GH, Felgner PL, Dwarki VJ, Gromkowski SH, Deck RR, DeWitt CM, Friedman A, et al. (1993) Heterologous protection against influenza by injection of DNA encoding a viral protein. Science 259:1745-1749.

van Doremalen N, Lambe T, Spencer A, Belij-Rammerstorfer S, Purushotham JN, Port JR, Avanzato VA, Bushmaker T, Flaxman A, Ulaszewska M, et al. (2020) ChAdOx1 nCoV-19 vaccine prevents SARS-CoV-2 pneumonia in rhesus macaques. Nature 586:578-582.

Volz E, Mishra S, Chand M, Barrett JC, Johnson R, Geidelberg L, Hinsley WR, Laydon DJ, Dabrera G, O'Toole Á, et al.; COVID-19 Genomics UK (COG-UK) consortium (2021) Assessing transmissibility of SARS-CoV-2 lineage B.1.1.7 in England. Nature 593:266-269.

Voss WN, Hou YJ, Johnson NV, Delidakis G, Kim JE, Javanmardi K, Horton AP Bartzoka F, Paresi CJ, Tanno Y, et al. (2021) Prevalent, protective, and convergent IgG recognition of SARS-CoV-2 non-RBD spike epitopes. Science 372:1108-1112.

Voysey M, Clemens SAC, Madhi SA, Weckx LY, Folegatti PM, Aley PK, Angus B, Baillie VL, Barnabas SL, Bhorat QE, et al.; Oxford COVID Vaccine Trial Group (2021a) Safety and efficacy of the ChAdOx1 nCoV-19 vaccine (AZD1222) against SARS-CoV-2: an interim analysis of four randomised controlled trials in Brazil, South Africa, and the UK. Lancet 397:99-111.

Voysey M, Costa Clemens SA, Madhi SA, Weckx LY, Folegatti PM, Aley PK, Angus B, Baillie VL, Barnabas SL, Bhorat QE, et al; Oxford COVID Vaccine Trial Group (2021b) Single-dose administration and the influence of the timing of the booster dose on immunogenicity and efficacy of ChAdOx1 nCoV-19 (AZD1222) vaccine: a pooled analysis of four randomised trials. Lancet 397:881-891. 
Wajnberg A, Amanat F, Firpo A, Altman DR, Bailey MJ, Mansour M, McMahon M, Meade P, Mendu DR, Muellers K, et al. (2020) Robust neutralizing antibodies to SARS-CoV-2 infection persist for months. Science 370:1227-1230.

Walls AC, Fiala B, Schäfer A, Wrenn S, Pham MN, Murphy M, Tse LV, Shehata L, O'Connor MA, Chen C, et al. (2020a) Elicitation of potent neutralizing antibody responses by designed protein nanoparticle vaccines for SARS-CoV-2. Cell 183:1367-1382.e17.

Walls AC, Park YJ, Tortorici MA, Wall A, McGuire AT, and Veesler D (2020b) Structure, function, and antigenicity of the SARS-CoV-2 spike glycoprotein. Cell 181:281-292.e6.

Walsh EE, Frenck Jr RW, Falsey AR, Kitchin N, Absalon J, Gurtman A, Lockhart S, Neuzil K, Mulligan MJ, Bailey R, et al. (2020) Safety and immunogenicity of two RNA-based Covid-19 vaccine candidates. N Engl J Med 383:2439-2450.

Wan J, Xing S, Ding L, Wang Y, Gu C, Wu Y, Rong B, Li C, Wang S, Chen K, et al. (2020) Human-IgG-neutralizing monoclonal antibodies block the SARS-CoV-2 infection. Cell Rep 32:107918.

Wang C, Li W, Drabek D, Okba NMA, van Haperen R, Osterhaus ADME, van Kuppeveld FJM, Haagmans BL, Grosveld F, and Bosch BJ (2020a) A human monoclonal antibody blocking SARS-CoV-2 infection. Nat Commun 11:2251.

Wang H, Zhang Y, Huang B, Deng W, Quan Y, Wang W, Xu W, Zhao Y, Li N, Zhang $\mathrm{J}$, et al. (2020b) Development of an inactivated vaccine candidate, BBIBP-CorV, with potent protection against SARS-CoV-2. Cell 182:713-721.e9.

Wang P, Nair MS, Liu L, Iketani S, Luo Y, Guo Y, Wang M, Yu J, Zhang B, Kwong PD, et al. (2021a) Antibody resistance of SARS-CoV-2 variants B.1.351 and B.1.1.7. Nature 593:130-135.

Wang Y, Zhang L, Sang L, Ye F, Ruan S, Zhong B, Song T, Alshukairi AN, Chen R, Zhang Z, et al. (2020c) Kinetics of viral load and antibody response in relation to COVID-19 severity. J Clin Invest 130:5235-5244.

Wang Z, Muecksch F, Schaefer-Babajew D, Finkin S, Viant C, Gaebler C, Hoffmann $\mathrm{HH}$, Barnes CO, Cipolla M, Ramos V, et al. (2021b) Naturally enhanced neutralizing breadth against SARS-CoV-2 one year after infection. Nature 595:426-431.

Wang Z, Schmidt F, Weisblum Y, Muecksch F, Barnes CO, Finkin S, SchaeferBabajew D, Cipolla M, Gaebler C, Lieberman JA, et al (2021c) mRNA vaccineelicited antibodies to SARS-CoV-2 and circulating variants. Nature 592:616-622.

Ward BJ, Gobeil P, Séguin A, Atkins J, Boulay I, Charbonneau P-Y, Couture M, D'Aoust M-A, Dhaliwall J, Finkle C, et al. (2021) Phase 1 randomized trial of a plant-derived virus-like particle vaccine for COVID-19. Nat Med 27:1071-1078.

Weinreich DM, Sivapalasingam S, Norton T, Ali S, Gao H, Bhore R, Musser BJ, Soo Y, Rofail D, Im J, et al.; Trial Investigators (2021) REGN-COV2, a neutralizing antibody cocktail, in outpatients with Covid-19. $N$ Engl J Med 384:238-251.

Weissman D, Alameh MG, de Silva T, Collini P, Hornsby H, Brown R, LaBranche CC, Edwards RJ, Sutherland L, Santra S, et al. (2021) D614G spike mutation increases SARS CoV-2 susceptibility to neutralization. Cell Host Microbe 29:23-31.e4

Wibmer CK, Ayres F, Hermanus T, Madzivhandila M, Kgagudi P, Oosthuysen B Lambson BE, de Oliveira T, Vermeulen M, van der Berg K, et al. (2021) SARSCoV-2 501Y.V2 escapes neutralization by South African COVID-19 donor plasma. Nat Med 27:622-625.

Wink PL, Volpato FCZ, Monteiro FL, Willig JB, Zavascki AP, Barth AL, and Martins AF (2021) First identification of SARS-CoV-2 lambda (C.37) variant in Southern Brazil. Infect Control Hosp Epidemiol [published ahead of print]

Winkler ES, Gilchuk P, Yu J, Bailey AL, Chen RE, Chong Z, Zost SJ, Jang H, Huang Y, Allen JD, et al. (2021) Human neutralizing antibodies against SARS$\mathrm{CoV}-2$ require intact $\mathrm{Fc}$ effector functions for optimal therapeutic protection. Cell 184:1804-1820.e16.

Wong SK, Li W, Moore MJ, Choe H, and Farzan M (2004) A 193-amino acid fragment of the SARS coronavirus $\mathrm{S}$ protein efficiently binds angiotensinconverting enzyme 2. J Biol Chem 279:3197-3201.

Woo PC, Lau SK, Wong BH, Tsoi HW, Fung AM, Kao RY, Chan KH, Peiris JS, and Yuen KY (2005) Differential sensitivities of severe acute respiratory syndrome (SARS) coronavirus spike polypeptide enzyme-linked immunosorbent assay (ELISA) and SARS coronavirus nucleocapsid protein ELISA for serodiagnosis of SARS coronavirus pneumonia. J Clin Microbiol 43:3054-3058.

World Health Organization (2020a) Laboratory biosafety guidance related to coronavirus disease (COVID-19). (http://www.who.int/publications/i/item/laboratorybiosafety-guidance-related-to-coronavirus-disease-(covid-19); accessed: April 24, 2021).

World Health Organization (2020b) SARS-CoV-2 mink-associated variant strainDenmark. (https://www.who.int/emergencies/disease-outbreak-news/item/2020 DON301; accessed: April 24, 2021).

World Health Organization (2021a) 34th WHO Regulatory Update on COVID-19. (http://www.who.int/publications/m/item/34th-who-regulatory-update-on-covid-19; accessed: April 24, 2021).
World Health Organization (2021b) Interim recommendations for use of the ChAdOx1-S [recombinant] vaccine against COVID-19 (AstraZeneca COVID-19 vaccine AZD1222, SII Covishield, SK Bioscience). (http://apps.who.int/iris/ bitstream/handle/10665/340920/WHO-2019-nCoV-vaccines-SAGE_recommendation-AZD1222-2021.2-eng.pdf; accessed: April 24, 2021).

World Health Organization (2021c) SARS-CoV-2 Variants. (https://www.who.int/en/ activities/tracking-SARS-CoV-2-variants/; accessed January 4, 2022).

World Health Organization (2021d) Technical brief: regulation of COVID-19 vaccines. (http://www.who.int/publications/m/item/annex-1st-technical-briefregulation-of-covid-19-vaccines; accessed: April 24, 2021).

World Health Organization (2021e) Vaccine equity. (http://www.who.int/campaigns/ vaccine-equity; accessed: September 30, 2021).

Wrapp D, Wang N, Corbett KS, Goldsmith JA, Hsieh CL, Abiona O, Graham BS, and McLellan JS (2020) Cryo-EM structure of the 2019-nCoV spike in the prefusion conformation. Science 367:1260-1263.

Wu K, Werner AP, Koch M, Choi A, Narayanan E, Stewart-Jones GBE, Colpitts T, Bennett H, Boyoglu-Barnum S, Shi W, et al. (2021) Serum neutralizing activity elicited by mRNA-1273 vaccine. $N$ Engl J Med 384:1468-1470.

Wu NC, Yuan M, Liu H, Lee CD, Zhu X, Bangaru S, Torres JL, Caniels TG, Brouwer PJM, van Gils MJ, et al. (2020a) An alternative binding mode of IGHV3-53 antibodies to the SARS-CoV-2 receptor binding domain. Cell Rep 33:108274

Wu Y, Wang F, Shen C, Peng W, Li D, Zhao C, Li Z, Li S, Bi Y, Yang Y, et al. (2020b) A noncompeting pair of human neutralizing antibodies block COVID-19 virus binding to its receptor ACE2. Science 368:1274-1278.

Xia S, Zhang Y, Wang Y, Wang H, Yang Y, Gao GF, Tan W, Wu G, Xu M, Lou Z, et al. (2021) Safety and immunogenicity of an inactivated SARS-CoV-2 vaccine, BBIBP-CorV: a randomised, double-blind, placebo-controlled, phase $1 / 2$ trial Lancet Infect Dis 21:39-51.

Xie X, Liu Y, Liu J, Zhang X, Zou J, Fontes-Garfias CR, Xia H, Swanson KA, Cutler M, Cooper D, et al. (2021) Neutralization of SARS-CoV-2 spike 69/70 deletion, E484K and N501Y variants by BNT162b2 vaccine-elicited sera. Nat Med 27:620-621.

Yasui F, Kai C, Kitabatake M, Inoue S, Yoneda M, Yokochi S, Kase R, Sekiguchi S, Morita K, Hishima T, et al. (2008) Prior immunization with severe acute respiratory syndrome (SARS)-associated coronavirus (SARS-CoV) nucleocapsid protein causes severe pneumonia in mice infected with SARS-CoV. J Immunol 181:6337-6348.

Yuan M, Liu H, Wu NC, Lee CD, Zhu X, Zhao F, Huang D, Yu W, Hua Y, Tien H et al. (2020) Structural basis of a shared antibody response to SARS-CoV-2. Science 369:1119-1123.

Yurkovetskiy L, Wang X, Pascal KE, Tomkins-Tinch C, Nyalile TP, Wang Y, Baum A, Diehl WE, Dauphin A, Carbone C, et al. (2020) Structural and functional analysis of the D614G SARS-CoV-2 spike protein variant. Cell 183:739-751.e8.

Zhang C and Zhou D (2016) Adenoviral vector-based strategies against infectious disease and cancer. Hum Vaccin Immunother 12:2064-2074.

Zhang W, Davis BD, Chen SS, Sincuir Martinez JM, Plummer JT, and Vail E (2021a) Emergence of a novel SARS-CoV-2 variant in Southern California. JAMA 325:1324-1326.

Zhang Y, Zeng G, Pan H, Li C, Hu Y, Chu K, Han W, Chen Z, Tang R, Yin W, et al. (2021b) Safety, tolerability, and immunogenicity of an inactivated SARS-CoV-2 vaccine in healthy adults aged 18-59 years: a randomised, double-blind, placebocontrolled, phase 1/2 clinical trial. Lancet Infect Dis 21:181-192.

Zhao J, Zhao J, and Perlman S (2010) T cell responses are required for protection from clinical disease and for virus clearance in severe acute respiratory syndrome coronavirus-infected mice. J Virol 84:9318-9325.

Zhu FC, Guan XH, Li YH, Huang JY, Jiang T, Hou LH, Li JX, Yang BF, Wang L, Wang WJ, et al. (2020a) Immunogenicity and safety of a recombinant adenovirus type-5-vectored COVID-19 vaccine in healthy adults aged 18 years or older: a randomised, double-blind, placebo-controlled, phase 2 trial. Lancet 396:479-488.

Zhu FC, Li YH, Guan XH, Hou LH, Wang WJ, Li JX, Wu SP, Wang BS, Wang Z, Wang L, et al. (2020b) Safety, tolerability, and immunogenicity of a recombinant adenovirus type- 5 vectored COVID-19 vaccine: a dose-escalation, open-label, nonrandomised, first-in-human trial. Lancet 395:1845-1854.

Zhu N, Zhang D, Wang W, Li X, Yang B, Song J, Zhao X, Huang B, Shi W, Lu R, et al.; China Novel Coronavirus Investigating and Research Team (2020c) A novel coronavirus from patients with pneumonia in China, 2019. N Engl J Med 382:727-733.

Zost SJ, Gilchuk P, Case JB, Binshtein E, Chen RE, Nkolola JP, Schäfer A, Reidy JX, Trivette A, Nargi RS, et al. (2020) Potently neutralizing and protective human antibodies against SARS-CoV-2. Nature 584:443-449. 